\title{
COLORADOSCHOOLOFMINES
}

EARTH•ENERGY•ENVIRONMENT

Division of ECONOMICS AND Business

WORKING PAPER SERIES

\section{Evaluating the Availability of Gallium, Indium, and Tellurium from Recycled Photovoltaic Modules}

\author{
Michael Redlinger \\ Roderick Eggert \\ Michael Woodhouse
}

\author{
Working Paper 2014-09 \\ http://econbus.mines . edu/working-papers/wp201409.pdf \\ Colorado School of Mines \\ Division of Economics and Business \\ 1500 Illinois Street \\ Golden, CO 80401
}

November 2014

(C) 2014 by the listed authors. All rights reserved. 
Colorado School of Mines

Division of Economics and Business

Working Paper No. 2014-09

November 2014

Title:

Evaluating the Availability of Gallium, Indium, and Tellurium from Recycled Photovoltaic Modules

Author(s):

Michael Redlinger

Division of Economics and Business

Colorado School of Mines

Golden, CO 80401-1887

miredlin@mines .edu

Roderick Eggert

Division of Economics and Business

Colorado School of Mines

Golden, CO 80401-1887

reggert@mines . edu

Michael Woodhouse

Strategic Energy Analysis Center

National Renewable Energy Laboratory

15013 Denver West Parkway, Golden, CO, 80401

michael. woodhouse@nrel.gov

\begin{abstract}
The use of thin-film copper indium gallium (di)selenide (CIGS) and cadmium-telluride (CdTe) in solar technologies has grown rapidly in recent years, leading to an increased demand for gallium, indium, and tellurium. In the coming years, recycling these elements from end-of-life photovoltaic (PV) modules may be an important part of their overall supply, but little is known about the economic feasibility and the potential quantities available. This article investigates the future role of PV recycling in supplying gallium, indium, and tellurium. The authors evaluate both the quantities available from recycling over the next century and the associated costs for recycling modules and reusing each mineral in PV manufacturing. The findings indicate that, in terms of technical potential, there may be significant quantities of each mineral potentially available from recycling CIGS and CdTe modules. In terms of costs, recovering each element from end-of-life $\mathrm{PV}$ modules and reusing it in PV manufacturing is estimated to cost more than the current raw mineral costs. These findings help improve the understanding of recycling's role in enabling higher levels of CIGS and CdTe cell production.
\end{abstract}

Keywords: recycling, thin-films, photovoltaic, PV, solar module, mineral availability, tellurium, indium, gallium 


\section{Introduction}

Although thin-film photovoltaic (PV) technologies cadmium-telluride (CdTe) and copper indium gallium (di)selenide (CIGS) comprise only about $10 \%$ of the current PV market [1] their production has grown rapidly in recent years. The strong light absorption characteristics and low manufacturing cost of CdTe [2] and CIGS [3] modules, may increase the contribution of these technologies to the total PV growth in the coming decades.

These technologies, however, require the use of the elements gallium (Ga), indium (In), selenium (Se), and tellurium ( $\mathrm{Te}$ ) — each of which has a relatively fragile supply. Lokanc et al. [4] discuss the reasons why supplies of these minerals are so considered. First, current production of each is small and these markets are susceptible to abrupt demand shocks from new end uses, such as the surge in demand for indium for flat-panel displays in the early 2000s. Next, the primary supply (i.e. production from ores) of each mineral comes as a by-product of another mineral, which is the associated main product (e.g., copper, in the case of tellurium). As by-products, each mineral's supply is vulnerable to changes in main-product supply. Moreover, producers have optimized their operations to efficiently produce the main product, and recovery of any byproducts is of secondary importance. Finally, these minerals are relatively rare in the earth's crust. The average crustal abundances of only 0.002 and 0.05 parts per million (ppm) place tellurium and indium among the rarest elements [5, 6]. Gallium is relatively more abundant, with an average crustal abundance of about 17 ppm (comparable to lead) [7], but none of these minerals are found in high-enough concentrations to be the principal mineral of an ore body. This is why it can be cost prohibitive to mine any one of these elements as the mineral of primary economic interest.

Due to these factors, the supply of each mineral from end-of-life products—commonly referred to as supply from "old scrap" - could be important in meeting total demand and enabling wider adoption of these thin-film PV technologies. The purpose of this article is to determine the potential for recovering these minerals from end-of-life PV modules for reuse in CIGS and CdTe cell manufacturing. ${ }^{1}$ The analysis examines the technical potential for PV deployment from old scrap mineral supply in terms of the quantity of PV cell production possible from gallium,

\footnotetext{
${ }^{1}$ Recycling gallium arsenide (GaAs) modules is not evaluated in this analysis, but the methodology applied here can be extended to GaAs.
} 
indium, and tellurium old-scrap supplies and the cost of recycling modules and reusing each element in PV cell manufacturing. In particular, it evaluates the gigawatts of CdTe cells that can be produced annually from tellurium recovered from end-of-life modules, and the contribution recovered tellurium makes to PV module manufacturing cost (measured in U.S. dollars per watt produced). This article also assesses the same factors for indium and gallium in CIGS cell production.

Section 2 describes the existing literature on availability of these minerals and PV recycling costs. Section 3 presents the model and model inputs employed in the analysis. Section 4 discusses the results and provides some sensitivity analysis. Section 5 states the conclusions of the research, remarks on the implications of the results, and gives suggestions for future work.

\section{Literature Review}

This section reviews existing literature and divides it into two types. The first type discusses the quantity of CdTe or CIGS modules that can be produced from recycling end-of-life modules, within the context of overall availability, and includes Fthenakis [8] and Hourai et al. [9]. The second type considers the cost of recycling CIGS and CdTe PV modules, and includes Fthenakis et al. [10], Choi and Fthenakis [11], and McDonald and Pearce [12].

Fthenakis [8] assesses the amount of CdTe and CIGS modules producible based on the availability of tellurium and indium from primary sources (from ores) and secondary sources (from recycling). In the most likely case, he finds that, while holding demand from other applications constant, the amount of primary and secondary tellurium production available for PV in 2050 could be on the order of about 3,000 and 1,000 tonnes, respectively. This translates to close to 100 gigawatts (GW) of CdTe production in 2050. Primary tellurium production is estimated to peak sometime between the years 2055 and 2060. By 2100, about 2,000 to 3,000 tonnes of tellurium should be available for use in PV, which could result in $150 \mathrm{GW}$ of annual CdTe module production, if the modules are competitive in the market.

In the most-likely case, primary and secondary indium production could be 700 and 200 tonnes per year, respectively, in the year 2050. This translates to about $80 \mathrm{GW}$ of CIGS manufacturing in 2050, if the technology is economic. By 2100, secondary indium could increase to about 700 
tonnes and primary supply may fall to 400 tonnes, which combine to enable $150 \mathrm{GW}$ of annual CIGS module production.

Hourai et al. [9] use system dynamics modeling to assess the availability of tellurium for use in CdTe cells. In the analysis, Hourai et al. incorporate primary tellurium by-product production from copper, main-product mining of tellurium, and recovery of tellurium from post-consumer waste. Copper production is modeled using a logistic function, with peak copper production occurring in approximately 2050 at up to nearly 40 million tonnes per year. Main-product tellurium mining comes from two known deposits totaling 2,700 tonnes, and also is modeled with a logistic function. In tellurium recycling from end-of-life PV modules, the authors assume $10 \%$ tellurium loss in module collection, $10 \%$ loss in tellurium separation, and a 30-year cell life. Hourai et al. present three cases (business as usual, dynamic, and optimistic), and find that tellurium available for PV in the year 2050 could be approximately 1,000 tonnes, 2,500 tonnes, and 3,500 tonnes in the three respective cases, which could result in annual CdTe module production of $\sim 5 \mathrm{GW}, 150 \mathrm{GW}$, and $250 \mathrm{GW}$, if economic.

Fthenakis et al. [10] estimate the cost manufacturers could pay to recycle CuInSe $\mathrm{e}_{2}$ modules to be \$0.08/W (in 1996 dollar terms) using a system of reverse recycling. Choi and Fthenakis [11] evaluate the profitability of CdTe module recycling using First Solar's recycling process as a case study. The findings indicate that, although base case recycling is not profitable, there are many cases in which recycling could become profitable; profitability greatly depends on the incoming module cost and the price of glass cullet. McDonald and Pearce [12] examine the profitability of recycling five different PV technologies, including CdTe and CIGS modules. They account for recycling cost, avoided disposal cost, credit for glass cullet, and the price of recovered semiconductor material. The research determined that CdTe module recycling would not be profitable but CIGS module recycling might be profitable.

The present analysis contributes to the current literature in three respects. One is that, to our knowledge, this is the first study that evaluates potential CIGS deployment from both gallium and indium available in end-of-life modules. Second, whereas previously published literature has estimated recycling cost or profitability, this article estimates both the recycling and reuse costs of each mineral and how these costs evolves over time. Finally, whereas prior literature focused on either the quantity of PV deployed or the recycling cost, this research estimates both quantity 
of deployment and mineral cost, to provide a more thorough assessment of potential PV deployment from end-of-life modules.

\section{Model and Inputs}

This section discusses the model and model inputs used in this analysis. The model has two main outputs. The first is the amount of annual PV production from old scrap mineral supply (e.g., the gigawatts of CdTe modules that can be deployed with tellurium available from recycled modules). The second is the cost of recovering an element from end-of-life modules and reusing it in PV manufacturing. This is measured in U.S. dollars-per-watt peak (direct current), and herein is referred to as the recycled mineral's contribution to PV manufacturing cost. The following sections discuss how these two outputs are calculated within the model.

\subsection{Photovoltaic Production from Old Scrap Supply}

Photovoltaic production or deployment measured in gigawatts peak (GWp) from old scrap supply in year $t$ is denoted by $D_{t}$ and calculated as shown in Equation 1.

$$
D_{t}=\frac{R_{t} * m}{I_{t}}
$$

Where

$R_{t}$ is old scrap supply of an element from recycled modules in year $t$ (tonnes)

$m$ is the PV technology's proportional share of mineral consumption among all end uses

$I_{t}$ is the material intensity of the element in either CdTe or CIGS modules (tonnes/GW).

Old scrap supply in year $t\left(R_{t}\right)$ is equal to use or consumption by the PV technology in year $t-L$ that is in turn recovered from recycled modules in year $t: R_{t}=r * C_{t-L}$, where $r$ is the efficiency in which the mineral is recovered from end-of-life modules, $L$ is the module life, and $C_{t-L}$ is consumption of the mineral by the PV technology in year $t-L$. For simplicity, we assume that module life is constant over time. The initial year used in this model (year $t=0$ ) represents the year 2005, the first year in which data on CdTe module deployment is available. 
For years $t<L$, where $L$ is the life of the module in years, no modules are recycled and there is no old scrap supply, so old scrap supply begins in year $t=L$. The year 2005 represents the start of significant tellurium use in CdTe modules from primary supply sources. With a fixed 25-year module life, recycling of the tellurium initially supplied in 2005 could begin in 2030 and is modeled to continue every 25 years. This assumes that modules are recycled immediately following their end of life and ignores the lag between when a module is recycled and when the recovered elements can be reused. The length of time required to recycle modules is not long enough to materially affect our results.

Total use or consumption in year $t-L$ is equal to the total of primary supply in year $t-L$ (denoted by $S_{t-L}$ ) and old scrap supply in year $t-L$ that is used by the PV technology: $C_{t-L}=m\left(S_{t-L}+R_{t-L}\right)$. The amount used in year $t-L$ that is available for recycling is only the amount that is embodied in PV modules, and not any amount used by the PV sector but lost during the manufacturing process. Losses that occur during PV manufacturing are accounted for in the model but are excluded from the model description here for purposes of simplification. Thus, old scrap supply in year $t$ is the amount supplied to PV in year $t-L$ which then is recovered at the end of the module's useful life: $R_{t}=r * C_{t-L}=r * m\left(S_{t-L}+R_{t-L}\right)$. This result can be substituted into Equation 1 to form Equation 2.

$$
D_{t}=\frac{r *\left(S_{t-L}+R_{t-L}\right) * m^{2}}{I_{t}} \text {. }
$$

In a similar manner, $R_{t-L}$ can be substituted with $r * m\left(S_{t-2 L}+R_{t-2 L}\right)$. All old scrap supply was at one point primary supply, and therefore this substitution can be continued back to an initial year prior to the start of recycling to express deployment as shown in Equation 3.

$$
: \sum_{i=1}^{N} r^{i} m^{i+1} S_{0}(1+g)^{t-i L}
$$

For a given year $\mathrm{t}$, where

$S_{0}$ is the tonnes of primary mineral supply in the initial year $t=0$ (tonnes) 
$g$ is the annual percent change in primary mineral supply

$N=[t / L]$ is the greatest integer that is less than or equal the quotient $t / L$

Figure 1 shows an example how PV production from old scrap supply in the year 2055 (year $t=50$ of the model) is calculated. This figure is best read by starting with production from old scrap supply in $2055\left(D_{50}\right)$ on the far right, which is a function of tonnes of old scrap supply in $2055\left(R_{50}\right)$, PV's share of the mineral's total use in $2055(\mathrm{~m})$, and the tonnes of the mineral required in a gigawatt of PV in $2055\left(I_{50}\right)$. Tonnes of old scrap supply in $2055\left(R_{50}\right)$ is the product of use in PV in 2030 (assuming a 25-year module life) and the efficiency in which the element is recovered from end-of-life modules $(r)$. Tonnes of the mineral used in PV in 2030 $\left(C_{25}\right)$, in turn, is a function of the primary supply in $2030\left(S_{25}\right)$, the old scrap supply in 2030 $\left(R_{25}\right)$, and PV's share of the mineral's total use in 2030. Old scrap supply in $2030\left(R_{25}\right)$ then is equal to the product of use in PV in $2005\left(C_{0}\right)$ and the efficiency of recovering the mineral from end-of-life modules. Finally, PV's consumption of the mineral in 2005 simply is the product of PV's share of total mineral use and the primary mineral supply $\left(S_{0}\right)$, because in 2005 there was no old scrap supply.

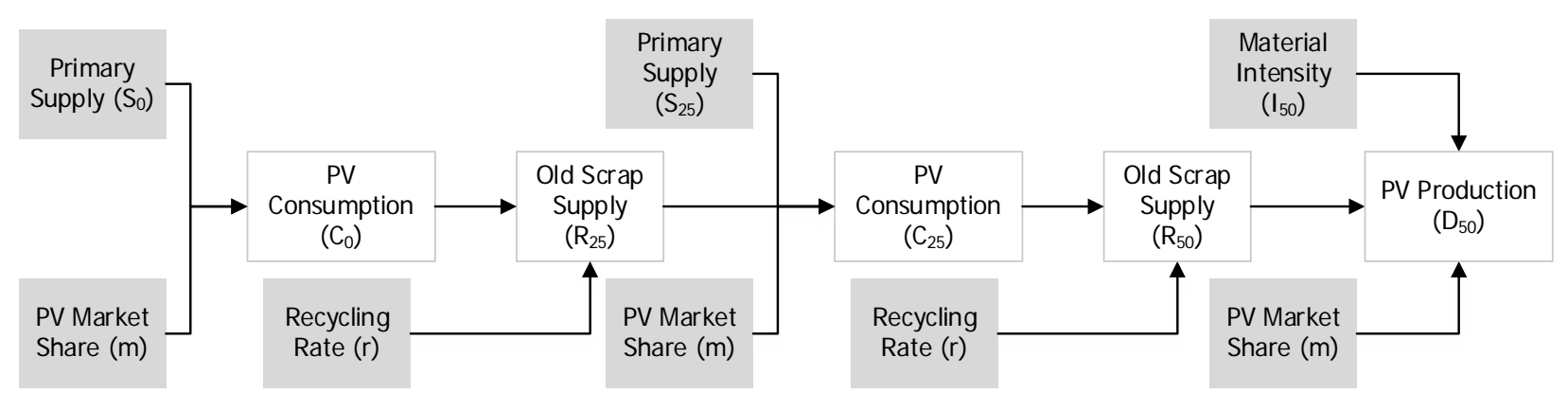

Figure 1. Deployment of PV from old scrap supply in 2055 (note that shaded boxes represent inputs to the model and unshaded boxes are outputs).

Equation 3 shows that the values needed for calculating $D_{t}$ are $I_{t}, \mathrm{~L}, r, m, S_{0}$, and $g$. Table 1 , Table 2, and Table 3 show the inputs and assumptions used to calculate each of these for three cases: Reference, Low PV Production, and High PV Production. 
Table 1. Module Material Efficiency and Layer Thickness Inputs

\begin{tabular}{|c|c|c|c|c|c|c|c|}
\hline & $\begin{array}{l}\text { Ga in } \\
\text { Cl GS }\end{array}$ & $\begin{array}{l}\text { In in } \\
\text { CIGS }\end{array}$ & $\begin{array}{l}\text { Te in } \\
\text { CdTe }\end{array}$ & & $\begin{array}{l}\text { Ga in } \\
\text { CI GS }\end{array}$ & $\begin{array}{l}\text { In in } \\
\text { CI GS }\end{array}$ & $\begin{array}{l}\text { Te in } \\
\text { CdTe }\end{array}$ \\
\hline Initial Efficiency $\left(\mathrm{W} / \mathrm{m}^{2}\right)^{a}$ & 157 & 157 & 128 & Initial Thickness $(\mu \mathrm{m})^{a}$ & 2 & 2 & 2.5 \\
\hline Max. Efficiency $\left(\mathrm{W} / \mathrm{m}^{2}\right)^{\mathrm{b}}$ & 208 & 208 & 196 & Min. Thickness $(\mu \mathrm{m})^{c}$ & 0.8 & 0.8 & 1 \\
\hline Efficiency Increase $^{d}$ & & & & Thickness Reduction ${ }^{d}$ & & & \\
\hline High (W/m²/year) & 6 & 6 & 6 & High (nm/year) & 75 & 75 & 112.5 \\
\hline Reference (W/ m² / year) & 4 & 4 & 4 & Reference ( $\mathrm{nm} /$ year) & 50 & 50 & 75 \\
\hline Low (W/m²/year) & 2 & 2 & 2 & Low (nm/year) & 25 & 25 & 37.5 \\
\hline $\begin{array}{l}\text { Current Material Intensity } \\
\text { (t/GW) }\end{array}$ & 7.5 & 23 & 69 & $\begin{array}{l}\text { Minimum Material } \\
\text { Intensity (t/GW) }\end{array}$ & 2.1 & 6.6 & 18.1 \\
\hline \multicolumn{8}{|c|}{$\begin{array}{l}\text { Notes: } \\
\text { a. Initial module efficiencies and layer thickness estimates are from Woodhouse et al. [13]. } \\
\text { b. Maximum efficiency is based on research best cell efficiency reported for each technology. } \\
\text { c. CdTe minimum layer thickness estimates are from Woodhouse et al. [14], and CIGS estimates are from Fthenakis [8]. } \\
\text { d. Reference Case improvement rates are based on Woodhouse et al. [14] for CdTe and on Fthenakis [8] for CIGS. Low and High } \\
\text { Cases are }-/+50 \% \text { of Reference Case. }\end{array}$} \\
\hline
\end{tabular}

Module efficiency increases and layer thickness decreases are assumed to progress at the rates specified in Table 1 until the maximum efficiency and minimum layer thickness levels are reached. The current and maximum material intensity values for gallium in CIGS, indium in CIGS, and tellurium in CdTe modules are 7.5, 23, and 69 tonnes per gigawatt [13], respectively. Material intensity over time is calculated by adjusting the material intensity equation specified in Woodhouse et al. [13] with improved efficiency and layer thickness levels. The decline in material intensity over time thus is exogenous to the model in that it is an input to the model that is unaffected by other elements of the model. The minimum material intensities associated with maximum efficiency and minimum layer thickness shown in Table 1are 2.1, 6.6, and 18.1 tonnes per gigawatt, respectively. Module life is 25 years, 20 years, and 30 years in the Reference, Low, and High cases, respectively, and is constant over time. That is, the model does not yet assume improvements in module life and assumes that no modules are recycled prior to or after their useful service life.

Table 2 shows the inputs for the recycling recovery efficiency for each mineral recycled from end-of-life modules, and for PV's share of total market consumption of each mineral. Based on information in existing literature $[9,15,16]$, we allow for $80 \%, 90 \%$, and $99 \%$ recovery 
efficiency of tellurium in Reference, Low, and High cases, respectively. Hourai et al. [9] assume $10 \%$ losses in collection and $10 \%$ losses in tellurium separation for $80 \%$ recovery efficiency. Fthenakis [15] estimates a range of recovery of 80-96\%, and First Solar [16] reports a recovery rate of $95 \%$. Little information is available regarding the efficiency in which gallium or indium can be recovered during CIGS module recycling, so the model makes the gross assumption that the efficiency rates are identical to that of tellurium in CdTe modules. This estimate for recovery from CIGS modules is higher than the $80 \%$ estimate provided in McDonald and Pearce [12].

Table 2. Recycling Efficiency and PV Consumption Inputs

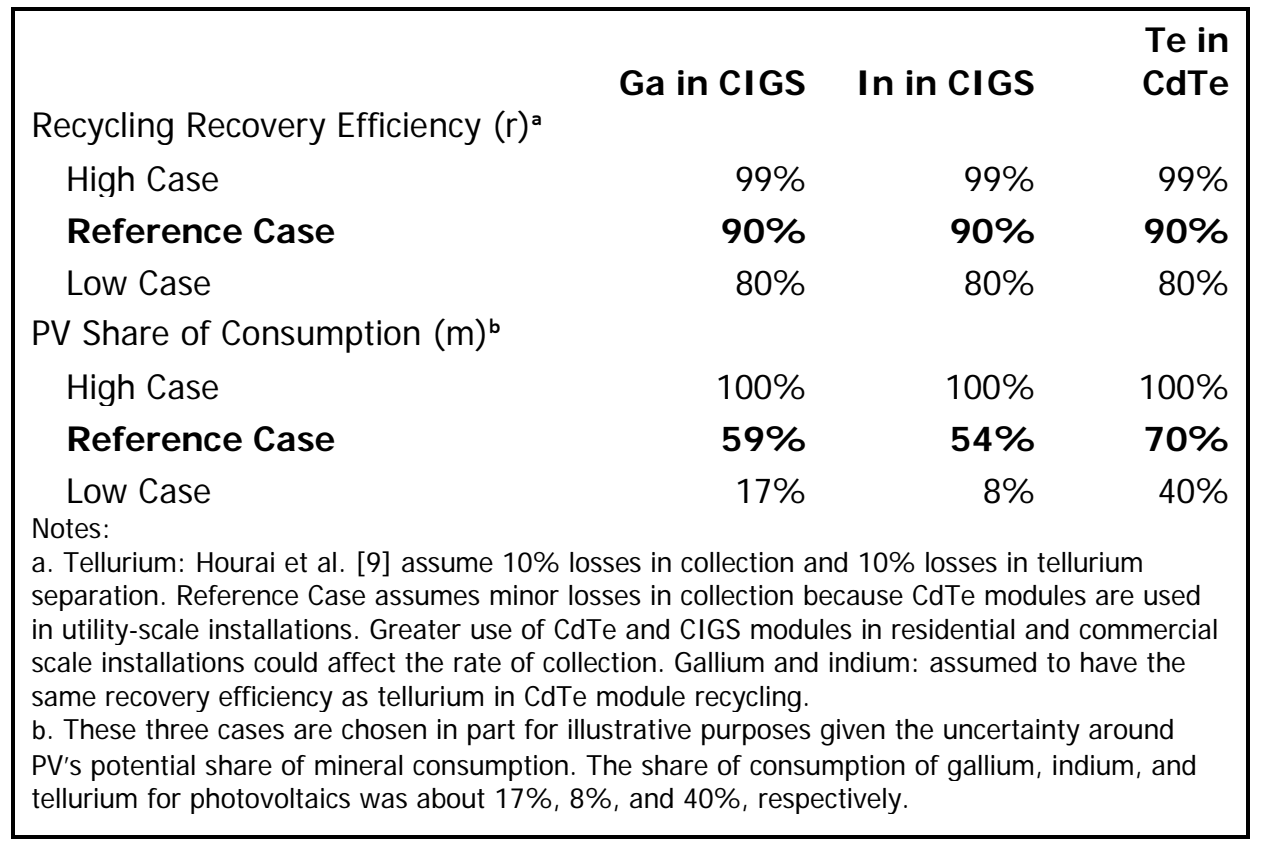

Currently, the PV sector's share of total gallium and indium consumption is quite small—only $17 \%$ and $8 \%$ - and its share of tellurium consumption is much greater at about $40 \%[17,18]$. There is much uncertainty regarding PV's share of total future mineral use, as it ultimately is determined by the PV sector's willingness to pay market price for a mineral relative to the willingness of other sectors to pay that price. Additionally, new technologies can substantially increase or decrease the demand for each mineral in other sectors. For example, substitute transparent conducting materials are actively being sought to replace the indium-tin-oxide used in flat-panel displays. Due to this uncertainty, the model used here provides a wide and optimistic range of potential market shares. For the Low case, the current share of mineral consumption by a technology is equal to its current share; the High case allows each PV 
technology to be the exclusive consumer of a mineral, and the Reference case is the average of the Low and High cases.

Table 3 shows the inputs that determine primary mineral supply in the model. The initial content of the gallium in bauxite ore, indium in zinc ore, and tellurium in copper anode slimes is the amount of each mineral that was available for recovery from these sources in 2012. The production growth rates show a range of potential production growth of bauxite, zinc, and copper. These rates are based on the average of the 30-year compound annual growth rates for 2003 to 2012. This differs from previous literature discussing tellurium and indium availability due to recycling $[9,10]$ in that this model does not show primary supply as peaking some time during the twenty-first century. Instead, the model has primary supply increasing through the year 2100 at rates consistent with historical production growth. In recent years there has been increased interest in the idea of "peak minerals," especially peak copper. Proponents of the "peak mineral theory" reason that the below-ground stock of any mineral is finite and thus exhaustion is inevitable [19, 20]. Opponents of this view counter that, historically, technology and innovation in mineral extraction have unlocked mineral deposits previously deemed uneconomic and thus have expanded world mineral resources [21]. There are many reasonable approaches to modeling primary mineral supply, and the present model allows for a range of potential production growth for the three cases presented.

Table 3. Primary Supply Inputs

\begin{tabular}{|lrrr|}
\hline & $\begin{array}{r}\text { Ga in } \\
\text { Bauxite }\end{array}$ & $\begin{array}{r}\text { In in } \\
\text { Zinc }\end{array}$ & $\begin{array}{r}\text { Te in } \\
\text { Copper }\end{array}$ \\
$\begin{array}{l}\text { Initial Content of Mineral in Ore or Slime } \\
\text { (tonnes) }^{\text {a }}\end{array}$ & 14,160 & 3,941 & 1,305 \\
$\begin{array}{l}\text { Production Growth of Ore or Slime (g) } \\
\quad \text { High Case (\%/year) }\end{array}$ & $4.1 \%$ & $2.6 \%$ & $2.0 \%$ \\
$\quad$ Reference Case (\% / year) & $\mathbf{3 . 2 \%}$ & $\mathbf{2 . 1 \%}$ & $\mathbf{1 . 6 \%}$ \\
$\quad$ Low Case (\%/year) & $2.4 \%$ & $1.7 \%$ & $1.8 \%$ \\
Mineral Recovery from Ore or Slime & & & \\
$\quad$ High Case Recovery Efficiency & $67 \%$ & $73 \%$ & $90 \%$ \\
$\quad$ Reference Case Recovery Efficiency & $\mathbf{4 7 \%}$ & $\mathbf{6 8 \%}$ & $\mathbf{8 0 \%}$ \\
$\quad$ Low Case Recovery Efficiency & $\mathbf{2 8 \%}$ & $64 \%$ & $70 \%$ \\
\hline
\end{tabular}


Notes:

a. Gallium and tellurium: Estimates of mineral available from main-product ores or slime;

indium estimates are from Lokanc et al. [4] Details can be found in the Appendix and in Lokanc

et al. [4]

b. Reference, Low, and High Cases are the average, minimum, and maximum of the 30 -year compound annual growth rates of production from 2003 to 2012.

c. Details of estimates can be found in the Appendix and in Lokanc et al. [4]

The mineral recovery efficiencies show the percentage of each mineral present in ores or in copper anode slime that can be recovered and refined. These estimates are based on the recovery efficiencies for current processes used to extract and refine each mineral. Gallium recovery from bauxite ores ranges from $28 \%$ to $67 \%$ according to our bottom-up assessment of potential gallium recovery during alumina production (See Appendix). Recovery of indium from zinc ores ranges from $64 \%$ to $73 \%$ according to Lokanc et al. [4]. Tellurium recovery ranges from $70 \%$ to 90\% according to our bottom-up analysis of tellurium recovery efficiency from copper anode slimes (See Appendix) and the existing estimates of potential recovery [23, 24]. (See the Appendix for more information about these estimates.)

Currently, only $2 \%$ of the gallium contained in bauxite ores is actually recovered tellurium recovery from anode slimes is about 35\% (see Appendix), and for indium it is $15 \%$ to $20 \%$ [4]. Whether each mineral will be recovered at such rates depends upon many factors, such as each mineral's price, the technological limitations on mineral recovery, and the demand of both PV and non-PV end uses. To evaluate the potential for old scrap supply when CdTe and CIGS modules are deployed on a larger scale, this analysis assumes relatively aggressive levels of mineral supply.

Despite the focus of this article being secondary supply, the assumptions made about primary supply over time have a significant impact on the results and thus merit additional discussion. The quantity of supply is assumed equal to consumption when markets are in equilibrium (ignoring inventories). Therefore, any projection of primary supply quantities requires consideration of the interaction of supply and demand forces.

\subsection{Mineral's Contribution to Photovoltaic Manufacturing Cost}

This section outlines the existing processes for recycling PV modules, and examines the estimated costs of recycling PV modules and reusing the recovered gallium, indium, or tellurium 
in either CIGS or CdTe module manufacturing. The recycling process discussed in this analysis thus considers the steps in collecting end-of-life modules; recycling modules to separate the semiconductor material and glass; recovering the gallium, indium, or tellurium metal; and reusing the recovered metals in PV manufacturing.

\subsubsection{Recycling Process}

For many years there has been academic interest in PV recycling from CIGS and CdTe modules [10, 24, 25, 26], but large-scale PV recycling has not existed due to limited PV production. The boom in solar demand in recent years has generated concern regarding end-of-life management of PV modules. In 2014, PV modules came under the scope of the European Union Waste Electrical and Electronic Equipment (WEEE) Directive, making PV manufacturers responsible for module recycling and disposal. In the United States, interest in PV recycling has grown [27], yet large-scale PV recycling still is many years away and there currently is little information on recycling processes and costs.

The largest producer of CdTe modules, First Solar, began a pre-funded recycling program in 2005 and has made public some information on its recycling process. Figure 2, adapted from Krueger [28], summarizes First Solar's current recycling process. In this process, modules are collected and transported to a facility where they are shredded and then crushed in a hammer mill. The semiconductor material (thin-film) is removed and separated from the glass, and the glass is cleaned and resold. The semiconductor material (CdTe filter cake) is separated into tellurium and cadmium by a third party. Methods for recycling CIGS modules are discussed by Fthenakis [24]. Modules are collected from utility-scale PV installations and shipped to a smelter for metal recovery and then further refining. Alternatively, smaller-scale operations could recycle modules and recover metals through ion-exchange, electrodeposition, or hydroxide precipitation. 


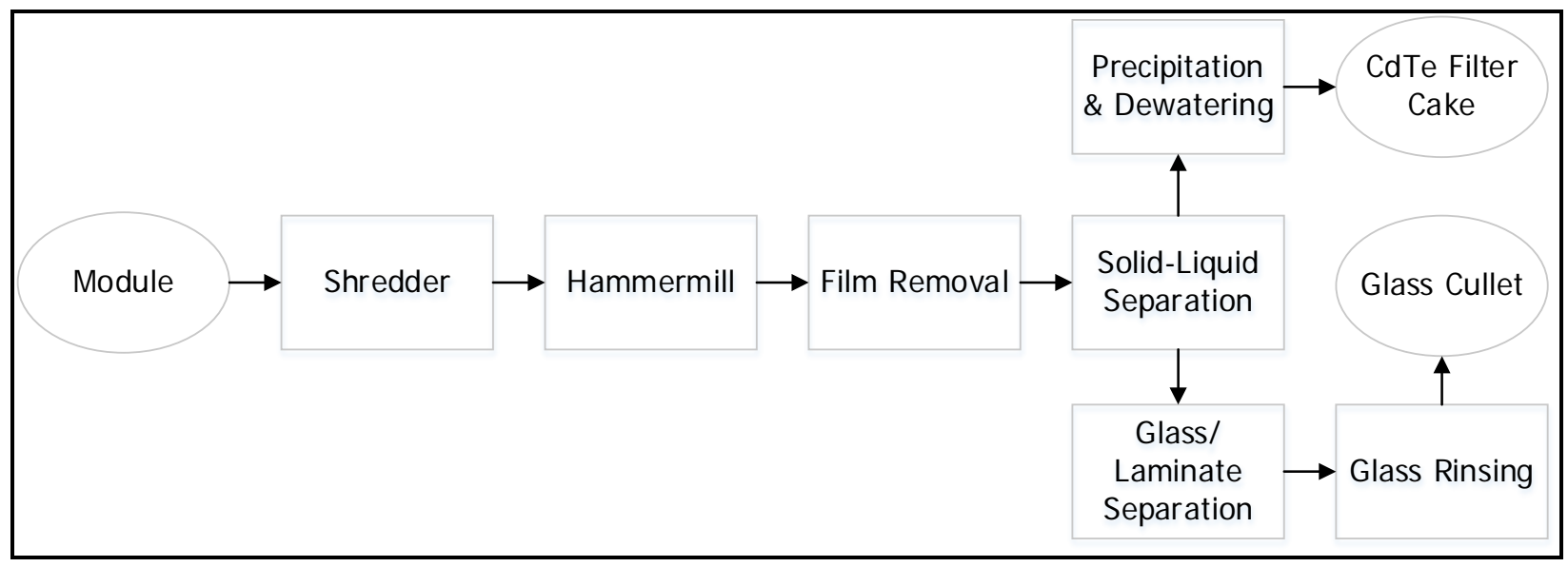

Figure 2. First Solar's current CdTe module recycling process, adapted from Krueger [28]. Oval objects represent physical inputs or outputs of the process, and rectangular objects represent steps in the process. More information on the process steps can be found in Krueger [28] and Choi and Fthenakis [11].

\subsubsection{Cost of Recycling and Reusing in PV}

The recycled mineral's contribution to PV manufacturing cost is calculated using Equation 4, adopted from Woodhouse et al. [15].

$$
C_{t}=\frac{I_{t}}{10^{6}}\left(\frac{\gamma_{t}(1-R)+T}{X(1-R)}\right)
$$

Where

$C_{t}$ is the contribution of the element to PV manufacturing costs in year $t(\$ / G W)$

$I_{t}$ is material intensity of the element in year $t(\mathrm{t} / \mathrm{GW})$

$\gamma_{t}$ is the cost of recovering the element from end-of-life modules in year $t(\$ / \mathrm{kg})$

$T$ is tolling cost to refine to solar grade $(\$ / \mathrm{kg})$

$R$ is the recovery fraction of the element in manufacturing

$X$ is the weight percent of the element in the compound

The values for $I_{t}$ are discussed in Section 3.1, and the values for $T, R$, and $X$ are taken from Woodhouse et al. [15] and are static over time. If module recycling costs (net of any credits received) in year $t$ (denoted by $\theta_{t}$, in $\$ / \mathrm{W}$ ) are allocated to the recovery of the element of interest here, then the cost per unit of mineral recovered can be expressed as shown in Equation 5. 


$$
\gamma_{t}=\frac{\theta_{t} * 10^{6}}{r * I_{t-L}}
$$

Where

$\theta_{t}$ is the module recycling cost in year $t(\$ / \mathrm{W})$

$r$ is the proportion of the mineral recovered during recycling

$I_{t-L}$ is the mineral's material intensity in year $t-L$ (tonnes/GW)

The recycling cost per watt $\left(\theta_{t}\right)$ is likely to change over time as modules become more efficient and as recycling expands and benefits from cost reductions through economies of scale and learning. To account for changes in module efficiency, recycling cost per watt is expressed as $\theta_{t}=\alpha / \eta_{t-L}$, where $\alpha$ is the recycling cost per square meter of module processed and $\eta_{t-L}$ is the area-based power rating $\left(\mathrm{W} / \mathrm{m}^{2}\right)$ of the module manufactured in year $t-L$. By assuming a fixed $\alpha$ and allowing the power conversion efficiency to change over time, the model accounts for how changes in module efficiency affect recycling costs. In particular, recycling costs (in \$/W) are modeled as inversely proportional to module efficiency or power rating. Note that one could account for economies of scale or learning by adjusting $\alpha$ over time, but this is not pursued herein due to a lack of information on the potential economies of scale and learning economies in PV recycling. To see how recycling cost in dollar per watt is inversely proportional to module efficiency, assume recycling first occurs in year $t=L$, from modules manufactured in year 0 . The resulting recycling cost in dollar per watt in year $L$ is $\theta_{L}=\alpha / \eta_{0}$ and hence $\alpha=\theta_{L} \eta_{0}$. Recycling cost in any year $t$ then can be expressed as $\theta_{t}=\alpha / \eta_{t-L}=\left(\theta_{L} \eta_{0}\right) / \eta_{t-L} \quad$. That is, recycling cost (in $\$ / \mathrm{W})$ is the product of the initial recycling cost $\left(\theta_{L}\right)$ and the ratio of efficiency in year 0 to efficiency in year $t-L$. Substituting this result into Equation 5 yields the following (Equation 6).

$$
\gamma_{t}=\frac{\theta_{l} * \eta_{0} * 10^{6}}{\eta_{t-L} * r * I_{t-L}} .
$$


The inputs for module power rating, recycling efficiency, and material intensity $\left(\eta_{0}, \eta_{t-L}, r\right.$, and $\left.I_{t-L}\right)$ are discussed in Section 3.1. The calculations behind the initial module recycling cost $\left(\theta_{L}\right)$ for each PV technology are found in Table 4, Table 5, and Table 6. For gallium and indium recycled from CIGS modules, $\theta_{L}$ is calculated from McDonald and Pearce [12], Choi and Fthenakis [11], and other publicly available information on CIGS modules and recycling. The recycling cost is the cost incurred during recycling, less any credit for module glass and for the avoided cost of disposal. Table 4 shows the CIGS module glass credit and avoided disposal cost, which are estimated at $\$ 0.021 / \mathrm{W}$ and $\$ 0.006 / \mathrm{W}$, respectively. This calculation does not take into account any credits for the recycled aluminum frame and the copper or selenium recovered, but if recovered, these would help reduce CIGS module recycling cost.

\section{Table 4. CIGS Module Recycling Glass Credit and Avoided Disposal Cost}

\begin{tabular}{lrclrc} 
CI GS Module Recycling Glass Credit & & Note/Source & CIGS Avoided Disposal Cost & & Note/Source \\
\hline Glass Density $\left(\mathrm{g} / \mathrm{cm}^{3}\right)$ & 2.6 & {$[12]$} & Weight of Module $\left(\mathrm{kg} / \mathrm{m}^{2}\right)$ & 17.5 & {$[12,29]$} \\
Glass Thickness $(\mathrm{cm})$ & 0.68 & {$[12]$} & Module Efficiency $\left(\mathrm{W} / \mathrm{m}^{2}\right)$ & 157 & {$[13]$} \\
Module Efficiency $\left(\mathrm{W} / \mathrm{m}^{2}\right)$ & 157 & {$[13]$} & Waste $(\mathrm{kg} / \mathrm{W})$ & 0.111 & $\mathrm{~d}$ \\
Glass Material Intensity $(\mathrm{t} / \mathrm{GW})$ & 112,611 & $\mathrm{a}$ & Waste Disposal Cost $(\$ / \mathrm{kg})$ & 0.05 & {$[12]$} \\
Glass Recycling Recovery $(\%)$ & 100 & {$[12]$} & Avoided Disposal Cost $(\$ / \mathrm{W})$ & 0.006 & $\mathrm{e}$ \\
Glass Recovery $(\mathrm{t} / \mathrm{GW})$ & 112,611 & $\mathrm{~b}$ & & & \\
Value of Recovered Glass $(\$ / \mathrm{t})$ & 187 & {$[11]$} & & & \\
Glass Credit $(\$ / \mathrm{W})$ & 0.021 & $\mathrm{C}$ & & & \\
\hline
\end{tabular}

Notes:

a. To calculated glass material intensity, the product of glass density and glass thickness is taken, then converted from $\mathrm{g} / \mathrm{cm} 2$ to tonnes $/ \mathrm{m} 2$. The result is divided by module efficiency and converted to tonnes per GW.

b. Glass recovery is the product of glass material intensity and the glass recycling recovery \%.

c. Glass credit is the production of glass recovery ( $t / G W)$ and the glass value $(\$ / t)$ and converted to $\$ / W$.

d. Waste $(\mathrm{kg} / \mathrm{W})$ is calculated as the weight of the module divided by the module efficiency.

e. Avoided disposal cost is the product of Waste $(\mathrm{kg} / \mathrm{W})$ and waste disposal cost $(\$ / \mathrm{kg})$.

Table 5 shows the current gross and net recycling cost for CIGS modules in cost per watt. The recycling cost net of all credits is the input parameter $\theta_{l}$. By allocating recycling cost for CIGS modules on a per-unit weight basis, the initial value of $\gamma_{t}$ for the two metals each equal 
$\$ 2,792 / \mathrm{kg}$ in real 2012 dollars. This cost is quite high relative to current gallium and indium metal prices of $\$ 200-300 / \mathrm{kg}$ and $\$ 700-800 / \mathrm{kg}$, suggesting that recycling costs must decline substantially or mineral market prices must rise significantly for module recycling to become economically compelling.

Table 5. CIGS Module Recycling Cost Estimates

\begin{tabular}{lrc}
\hline & & Note \\
\hline Gross Recycling Cost $(\$ / W)$ & 0.08 & $\mathrm{a}$ \\
ClGS Avoided Disposal $(\$ / \mathrm{W})$ & -0.006 & \\
Glass Credit $(\$ / \mathrm{W})$ & -0.021 & \\
Net Recycling Cost $(\$ / \mathrm{W})$ & 0.053 & $\mathrm{~b}$ \\
Gallium Content $(\mathrm{t} / \mathrm{GW})$ & 5.1 & $\mathrm{c}$ \\
Indium Content $(\mathrm{t} / \mathrm{GW})$ & 16.1 & $\mathrm{c}$ \\
Gallium Recovered $(\mathrm{t} / \mathrm{GW})$ & 4.6 & $\mathrm{~d}$ \\
Indium Recovered $(\mathrm{t} / \mathrm{GW})$ & 14.5 & $\mathrm{~d}$ \\
& & \\
Gallium Recycling Cost $(\$ / \mathrm{kg})$ & 2,792 & $\mathrm{e}$ \\
Indium Recycling Cost $(\$ / \mathrm{kg})$ & 2,792 & $\mathrm{e}$ \\
\hline
\end{tabular}

Notes:

a. From Fthenakis et al. [10]

b. Net recycling cost $=$ Gross - Avoided Disposal - Glass Credit.

c. Gallium and indium content is the material intensity adjusted for losses during manufacturing.

d. Gallium and indium recovered assumes $90 \%$ recovery efficiency.

e. Gallium and indium recycling cost per kilogram are identical because costs are allocated based on unit weight.

The recycling cost for CdTe modules is estimated based on information provided in First Solar's annual filings with the Securities and Exchange Commission (SEC). In 2005, First Solar started a program to pre-fund end-of-life module recycling by setting aside and investing an amount equal to the expected present value of future recycling costs. Over time, this investment grows to cover the cost of recycling modules at the end of their useful lives. For example, in 2009 First Solar recognized an expense of $\$ 52.4$ million for future recycling costs attributable to sales of PV modules during 2009. First Solar is estimated to have sold 1,067 MW of PV modules in 2009, implying that the present value of its recycling obligation or expected recycling cost averaged $\$ 0.049 / W$. In 2010, First Solar reported in its 2009 10-K SEC filing that it pre-funds recycling by depositing funds into “...a custodial account with a large bank as investment advisor in the name 
of a trust, for which First Solar Inc., First Solar Malaysia Sdn. Bhd., and First Solar Manufacturing GmbH are grantors.”, and the funds are invested in U.S. bonds and other government bonds [30]. Hence one can estimate the future value recycling cost (in current or nominal terms) by assuming that amount set aside today grows at a rate consistent with the nominal interest rate of these government bonds in order to cover later recycling costs. In turn, using an assumption about inflation between now and when the recycling costs will be incurred, we can estimate the cost of recycling in real 2012 dollars.

Table 6 shows the calculation made for estimating the cost of recycling CdTe modules. The Reference Case uses the estimated recycling cost for modules sold during 2011, which is $\$ 0.043 / \mathrm{W}$, and $+/-50 \%$ of this value is used for the Low and High Cases, respectively. Note that the Low and High cases refer to the levels of CdTe and CIGS module production, and low (high) production corresponds to a relatively higher (lower) recycling cost. The Reference Case estimate is consistent with estimates from Fthenakis [15] of \$0.05/W recycling cost, and the McDonald and Pearce [12] estimate of a recycling cost of $9.00 / \mathrm{m}^{2}$ or $\$ 0.057 / \mathrm{W}$, with a sunlight power conversion efficiency of $15.7 \%\left(157 \mathrm{~W} / \mathrm{m}^{2}\right)$.

Table 6. Estimated CdTe Module Recycling Cost

\begin{tabular}{lrrrc}
\hline & $\mathbf{2 0 0 9}$ & $\mathbf{2 0 1 0}$ & $\mathbf{2 0 1 1}$ & Note \\
\hline Present Value of Recycling Obligation & & & & \\
Charged to Cost of Sales (\$ Millions) & $\$ 52.4$ & $\$ 45.0$ & $\$ 38.3$ & $\mathrm{a}$ \\
Module Sales (MW) & $1,066.7$ & $1,365.4$ & $1,461.0$ & $\mathrm{a}$ \\
PV of Recycling Obligation (PV \$/W) & $\$ 0.049$ & $\$ 0.033$ & $\$ 0.026$ & \\
Estimated Life of Modules (Years) & 25 & 25 & 25 & $\mathrm{~b}$ \\
Estimated Rate of Return (\%/Year) & 4.08 & 4.25 & 3.91 & $\mathrm{C}$ \\
Future Value of Recycling Cost (\$/W) & $\$ 0.133$ & $\$ 0.093$ & $\$ 0.068$ & $\mathrm{~d}$ \\
Year of Recycling & 2034 & 2035 & 2036 & \\
Inflation Rate (\%/Year) & $2.0 \%$ & $2.0 \%$ & $2.0 \%$ & $\mathrm{e}$ \\
Recycling Cost (Real \$ per Watt) & $\$ 0.081$ & $\$ 0.057$ & $\$ 0.042$ & $\mathrm{f}$ \\
Recycling Cost (2012 \$ per Watt) & $\$ 0.087$ & $\$ 0.060$ & $\$ 0.043$ & $\mathrm{~g}$ \\
\hline
\end{tabular}

Notes: 
a. Sources for recycling obligation and modules sales are annual $10-\mathrm{K}$ filings with the SEC [30, 31, 32].

b. Module-life estimates are the author's own estimates based on expected module life information in annual FSLR 10-K filings with the SEC.

c. Rate of return information is the author's own estimate based on information about FSLR's pre-funded recycling program in annual FSLR 10-K SEC filings. The rates are equal to the 30-year Treasury Constant Maturity Rate for the year the obligation was incurred.

d. Calculated as FV $=P V(1+r) L$, where PV is present value recycling obligation, $r$ is the annual rate of return earned on the recycling obligation, and $L$ is the module life.

e. Source for inflation rate is the Energy I nformation Administration (EIA) longterm projection of inflation (2013).

f. Calculated as Real Value $=F V /(1+i) L$, where $i$ is the inflation rate and $L$ is the module life.

g. Adjusted to real 2012 dollars using the U.S. CPI-U (e.g., \$0.042*(2012 CPI / 2011 CPI ) $=\$ 0.043$.

\section{Results and Sensitivity Analysis}

This section discusses the results from the model and provides a simple sensitivity analysis. As previously mentioned, the two main outputs are the amount of PV production from old scrap supply and each mineral's contribution to PV manufacturing cost; both are presented in the next three figures. The cost measured in U.S. dollars per watt deployed is on the vertical axis and the size of each bubble represents the amount of PV production that could result from old scrap supply. Results from the three cases, Reference, Low PV production, and High PV production are shown in gray, black, and white with a black border, respectively.

\section{Results}

Figure 3 shows that relatively large quantities of CdTe modules are technically producible from old scrap tellurium supply compared to current production levels of a couple gigawatts per year. The recovered tellurium's contribution to PV manufacturing costs, however, are higher than current costs based on supplies from primary tellurium production (supply from ores). In the Reference Case, tellurium costs in real 2012 dollar terms grow from $\$ 0.03 / \mathrm{W}$ around 2040 to $\$ 0.07 / \mathrm{W}$ in 2060 and remain flat at $\$ 0.07 / \mathrm{W}$ thereafter. In the Low CdTe module production case, which corresponds to higher tellurium costs, tellurium costs initially decline and then rise to $\$ 0.12 / \mathrm{W}$ around 2075 . In the High CdTe module production case, costs increase from $\$ 0.015 / \mathrm{W}$ around 2040 to $\$ 0.035 / \mathrm{W}$ in 2060 . Note that these estimates do not account for 
economies of scale or learning economies, which could reduce costs further. Current tellurium cost in CdTe module manufacturing is estimated to be $\$ 0.034 / \mathrm{W}$ [11].

The movement of cost over time deserves some mention, in particular the decline and rise in cost in the Low CdTe module production case. In this model, changes in material intensity are what drive the change in cost over time. The direct effect of lower material intensity is that less tellurium is required per watt deployed, which bring down the tellurium cost per watt. There is an indirect effect of lower material intensity because less tellurium is present per watt of CdTe modules recycled at the end of its useful life. This reduced concentration of tellurium increases recycling cost (in terms of $\$ / \mathrm{W}$ recycled) because for each watt recycled, less tellurium is recovered.

These two effects of declining material intensity influence cost for all three cases, as shown in Figure 3, Figure 4, and Figure 5 (for tellurium, indium, and gallium), but are more obvious in the Low PV production case. In the Low Case, costs initially fall as the reduced tellurium material intensity requires less tellurium per watt deployed, and direct cost decreases dominate. When the lower bound of tellurium material intensity is reached in manufactured modules (in the Low Case, 18.1 tonnes/GW in the year 2054), the quantity of tellurium in models has stabilized. Tellurium, however, is recovered from modules with lessening tellurium concentration and, consequently, its cost increases. Eventually, once the material intensity of tellurium in recycled CdTe modules stabilizes costs then stabilize. Tellurium costs in the Reference Case and High Case do not follow the exact pattern of the Low Case, because material intensity declines much more rapidly in these cases than it does in the Low Case. Thus, once PV recycling begins in the Reference and High cases, PV modules being manufactured already are at the lower material intensity, and costs increase as tellurium is recovered from modules with lessening tellurium concentration. As in the Low Case, the material intensity of tellurium in recycled CdTe modules eventually stabilizes and costs then stabilize. 


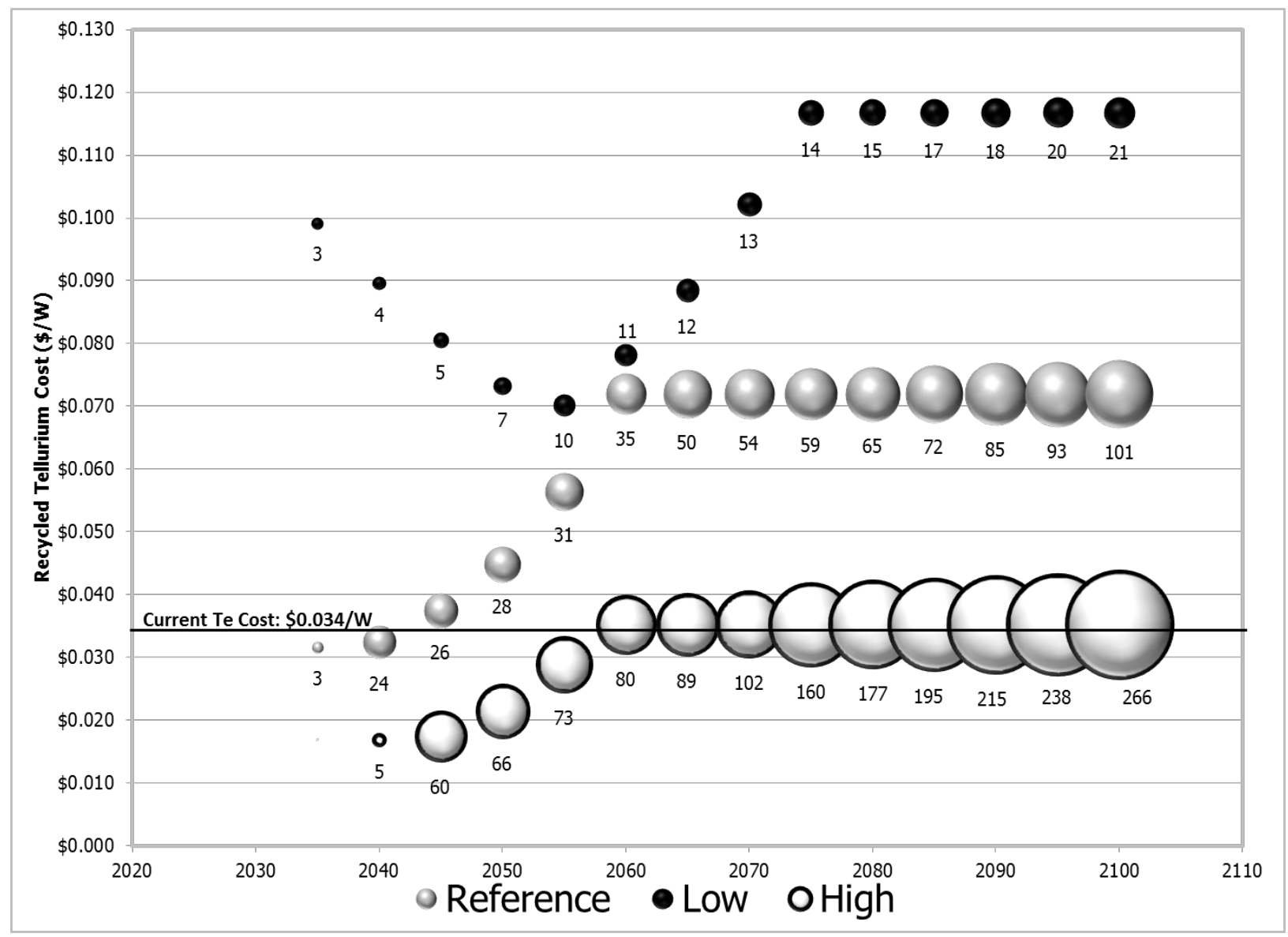

Figure 3. Recycled tellurium contribution to PV manufacturing cost and potential CdTe module deployment from old scrap supply. The vertical axis shows the recycled tellurium cost contribution to total module cost in 2012 U.S. dollars per watt of deployed CdTe, the horizontal axis is the year of CdTe deployment, and the size of the bubbles represents the estimated technical potential of production (GW) from old scrap tellurium supply.

As with tellurium in CdTe modules, there is a wide range of potential production and indium costs in CIGS module manufacturing (Figure 4). In the Reference Case, indium costs rise from about $\$ 0.02 / \mathrm{W}$ in the 2040s to $\$ 0.05 / \mathrm{W}$ around 2065 and remain constant thereafter. CIGS module production from old scrap indium supply begins in the 2040s and production grows thereafter. As in the case of tellurium in CdTe modules, large amounts of CIGS modules can be produced from old scrap indium supply relative to current CIGS module production, yet recycled indium's contribution to PV manufacturing costs are generally higher than current market costs of approximately $\$ 0.018 / \mathrm{W}[11]$. 


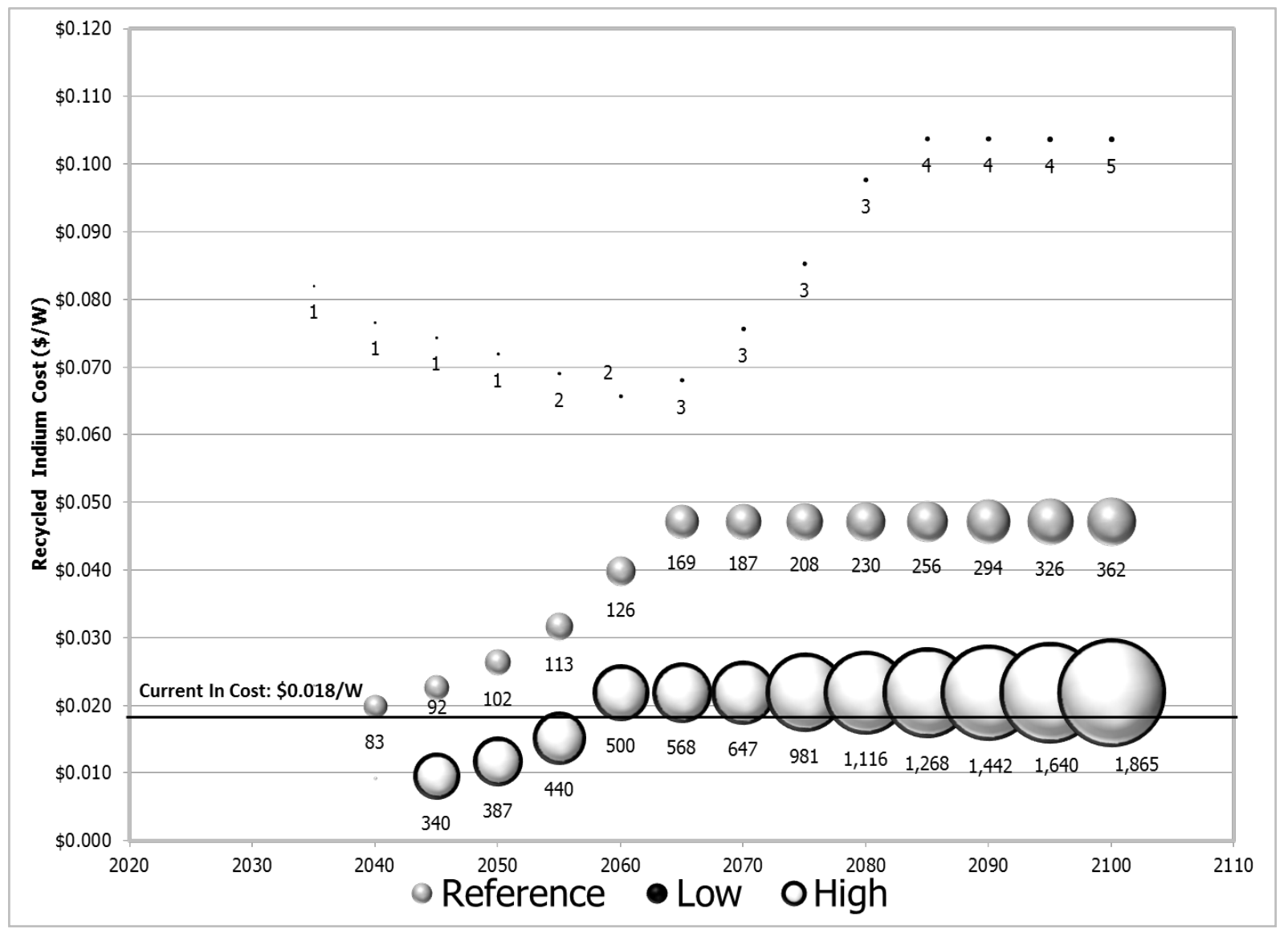

Figure 1. Recycled indium contribution to PV manufacturing cost and potential CIGS deployment from old scrap supply. The vertical axis shows the recycled indium cost in 2012 U.S. dollars per watt of deployed CIGS, the horizontal axis is year of CIGS deployment, and size of bubbles represents the estimated technical potential of deployment (GW) from old scrap indium supply.

Figure 5 shows that more CIGS modules could potentially be deployed from old scrap gallium supply as compared to old scrap indium supply, as reflected in the lower cost per watt. This primarily is influenced by the stoichiometry of each element in CIGS modules. In this case, less gallium is required per gigawatt in comparison to the amount of indium required, although the relative amounts of gallium and indium used in CIGS modules varies between manufacturers. There also are significantly greater levels of gallium primary supply than indium primary supply. Thus, in this analysis, indium is the mineral that potentially would impede CIGS deployment. The cost of gallium used in CIGS modules generally is less than the cost of indium, per W produced. This is due to the lower material intensity of gallium in CIGS modules as compared to indium, which is initially 7.5 tonnes/GW compared to indium's 23 tonnes/GW. Recycled gallium 
costs are still much greater than current gallium market costs, which is estimated to be $\$ 0.005 / \mathrm{W}$ [13].

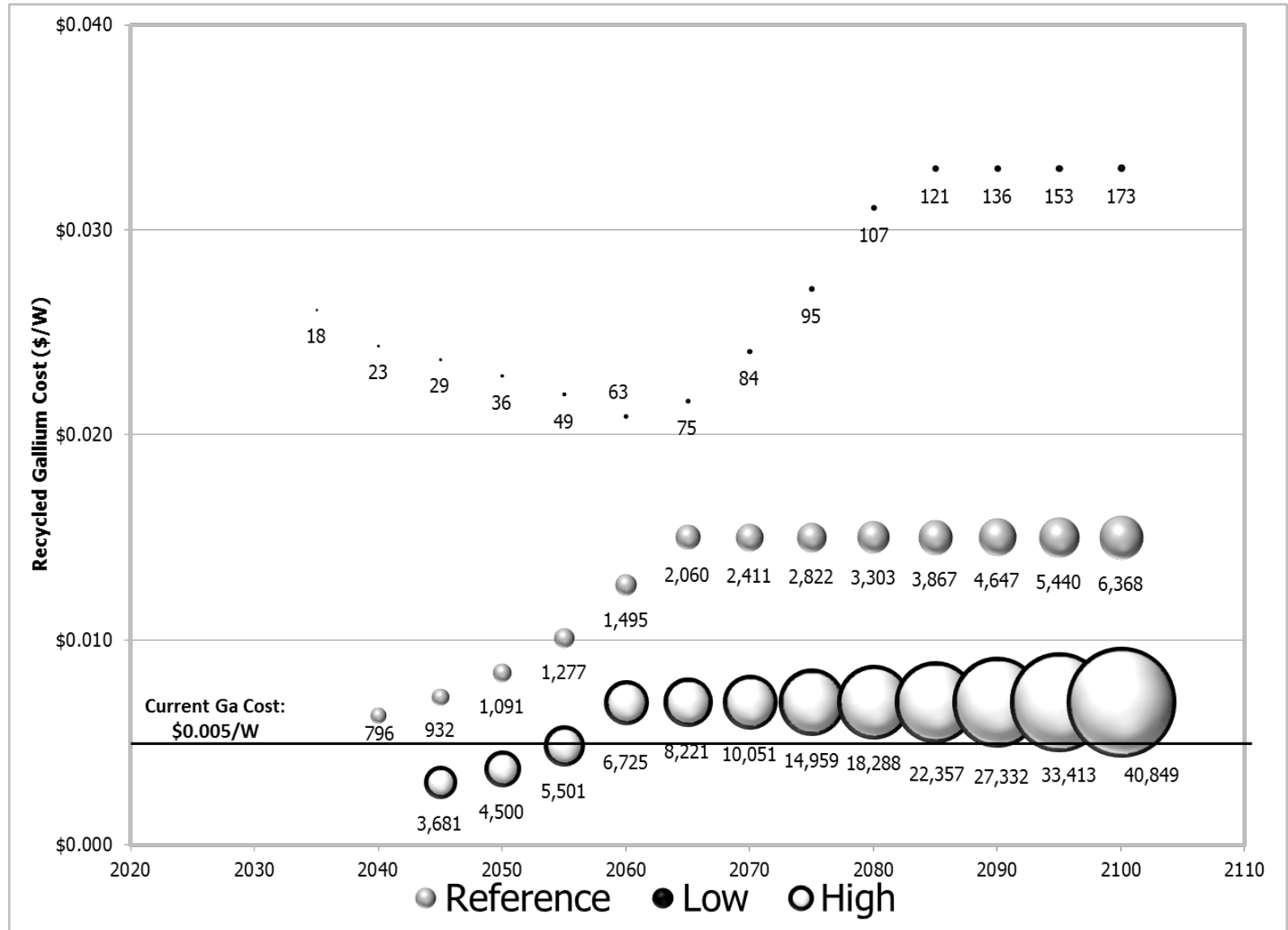

Figure 5. Recycled gallium contribution to PV manufacturing cost and potential CIGS deployment from old scrap supply. The vertical axis shows the recycled gallium cost in 2012 U.S. dollars per watt of deployed CIGS, the horizontal axis is the year of CIGS deployment, and size of the bubbles represents the estimated technical potential of deployment (GW) from old scrap gallium supply.

These figures do not include PV production from primary mineral supply, which this model assumes to be a significant source of the gallium, indium, and tellurium used in CIGS and CdTe modules. Figure 6 shows technically possible ${ }^{2}$ annual CdTe production over time based on both primary and secondary/recycled supply of tellurium for the cases. By the year 2100, annual CdTe

2 The results of the analysis do not indicate the amount of CdTe and CIGS that will be deployed - only what can be deployed. Technical feasibility is a maximum possible - then the reality of economics sets in and tells you what is economically possible. The reality of what is deployed will be less than what is economically feasible in most cases, which is less than the amount economically possible and is less than the amount technically feasible. 
module production technically feasible is approximately 300 GW (Reference), 100 GW (Low), and $600 \mathrm{GW}$ (High). In all cases, technically feasible CdTe module production from primary supply tellurium comprises the majority of total deployment: 67\% (Reference), 79\% (Low), and $58 \%$ (High).

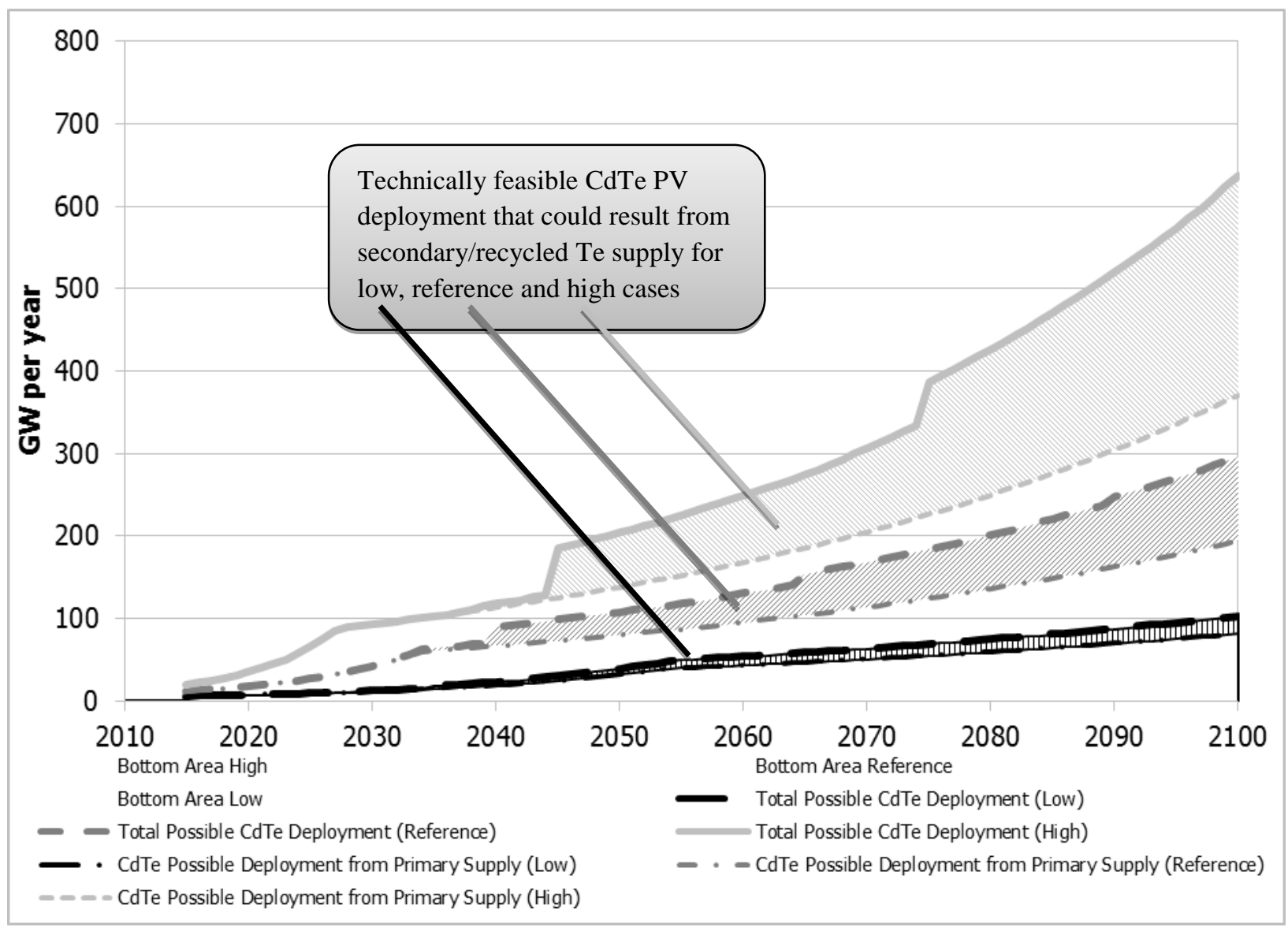

Figure 6. Technically feasible annual CdTe PV production from primary and secondary tellurium supply.

Figure 7 presents technically possible annual CIGS module production based on primary and secondary indium supply. Again there is a wide range of technically feasible installed capacity across the three cases. By the year 2100, annual CIGS module production could reach about 1,700 GW (Reference Case), 150 GW (Low Case), and 6,000 GW (High Case). Additionally, indium from primary sources comprises the vast majority of total indium supplied to the PV 
sector. CIGS installed capacity from primary supply makes up 80\% (Reference), 97\% (Low), and $70 \%$ (High) of total installed capacity.

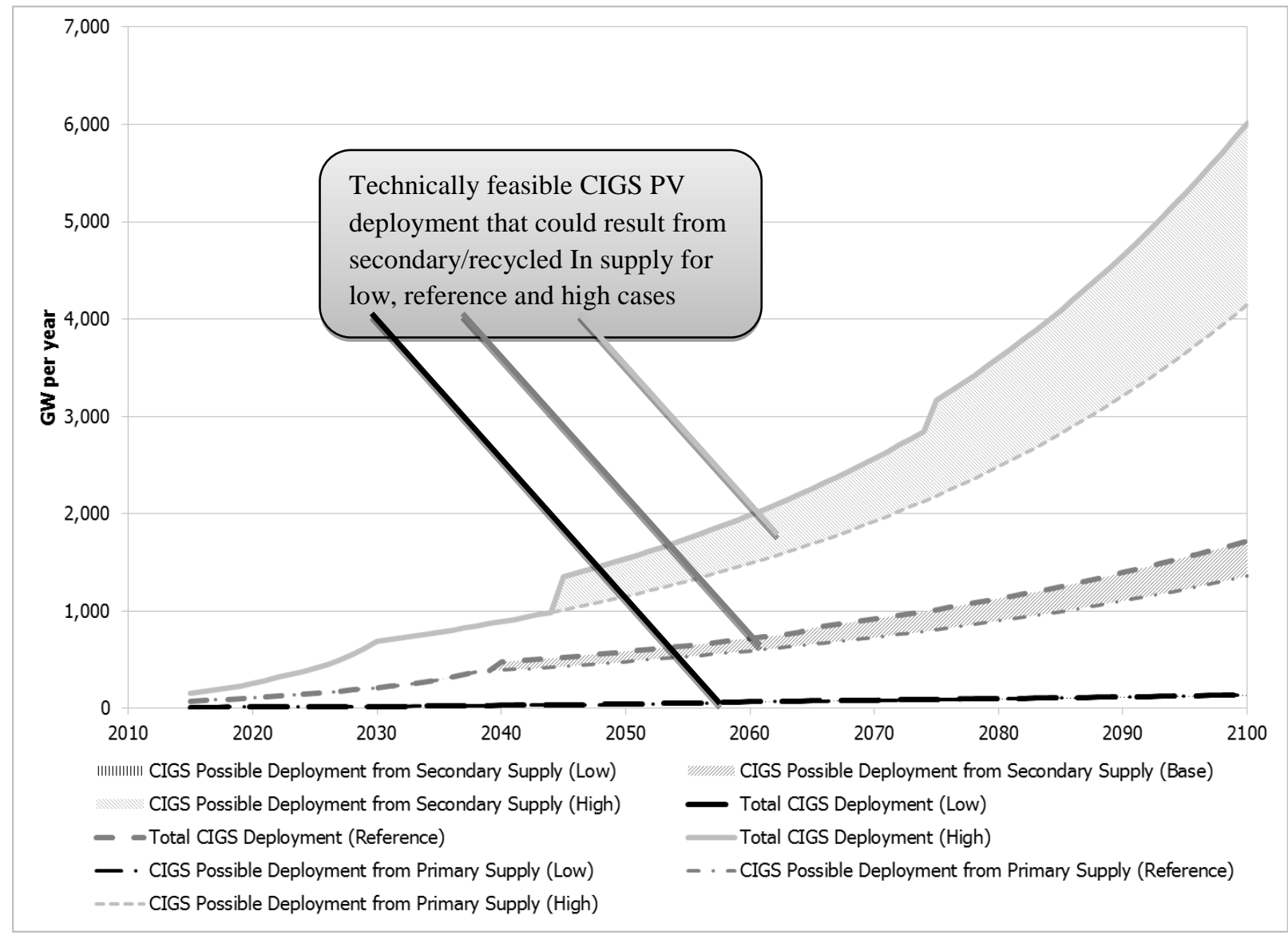

Figure 7. Technically feasible annual CIGS production from primary and secondary indium supply.

The technically feasible levels of annual CIGS module production based on gallium availability (Figure 8) are substantially higher than that based on indium availability alone. Annual CIGS module production could range from 3,000 GW (Low Case), to 195,000 GW (High Case), with a midpoint of 36,000 GW (Reference Case). Again, primary supply is the dominant source of gallium used in the PV sector, with between $80 \%$ and $90 \%$ of annual production in the year 2100 coming from primary gallium supply. These values are an order of magnitude greater than annual production based on indium availability, therefore this case has less relevance since indium is the limiting element for CIGS module production. 


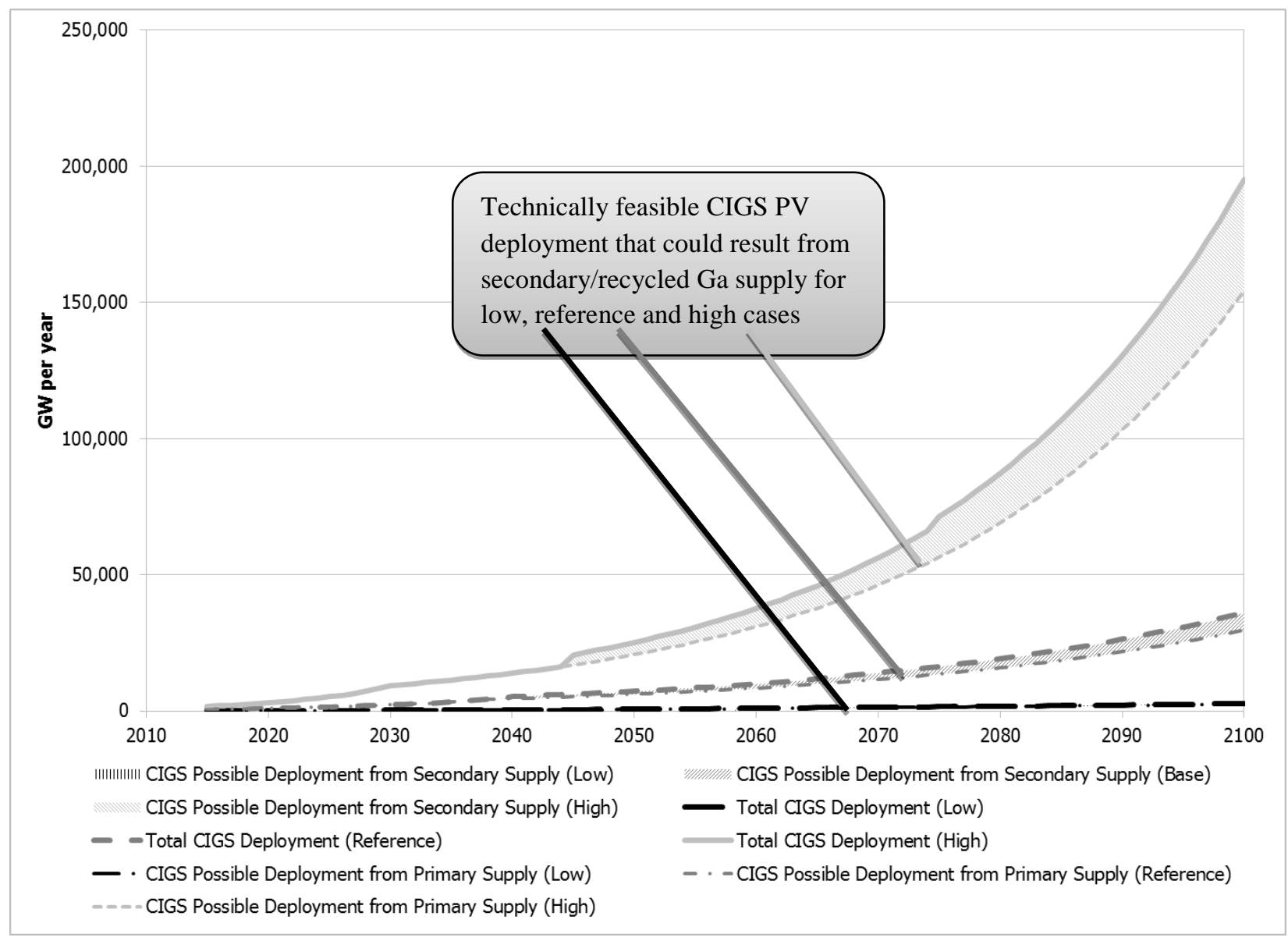

Figure 8. Technically feasible annual CIGS production from primary and secondary gallium supply (ignoring limitations on In supply shown in Figure 7).

\section{Sensitivities}

These results show a wide range of technically possible CIGS and CdTe module deployment (ignoring economics, so the maximum possible) and gallium, indium, and tellurium costs. This is a direct result of the uncertainty in the parameters of the present model. To understand which factors drive the variation in installed capacity from old scrap supply among the three minerals, this article provides some simple sensitivity analysis in Figure 9, Figure 10, and Figure 11. These figures show the change in cumulative technically feasible installed capacity in the year 2100 when there is a $-/+10 \%$ change in one input and all other inputs remain constant. 
As shown for all three elements, the variation in PV's share of total mineral consumption in the market and the mineral recovery efficiency in recycling have the greatest impact on installed capacity levels in 2100. A 10\% decrease in market share from the Reference Case levels reduces technically feasible installed capacity from old scrap supply in 2100 by $20 \%$ in the case of gallium in CIGS modules, 21\% in the case of indium in CIGS modules, and 22\% in the case of tellurium in CdTe modules. Adjustments to maximum module efficiency, mineral recovery efficiency, initial mineral availability and minimum layer thickness have moderate impacts that are all about similar across all three minerals. Changes in module life and production growth of the main product have the least impact on technically feasible installed capacity in the year 2100, except for gallium, for which a $10 \%$ change in bauxite production growth generates the second most significant effect.

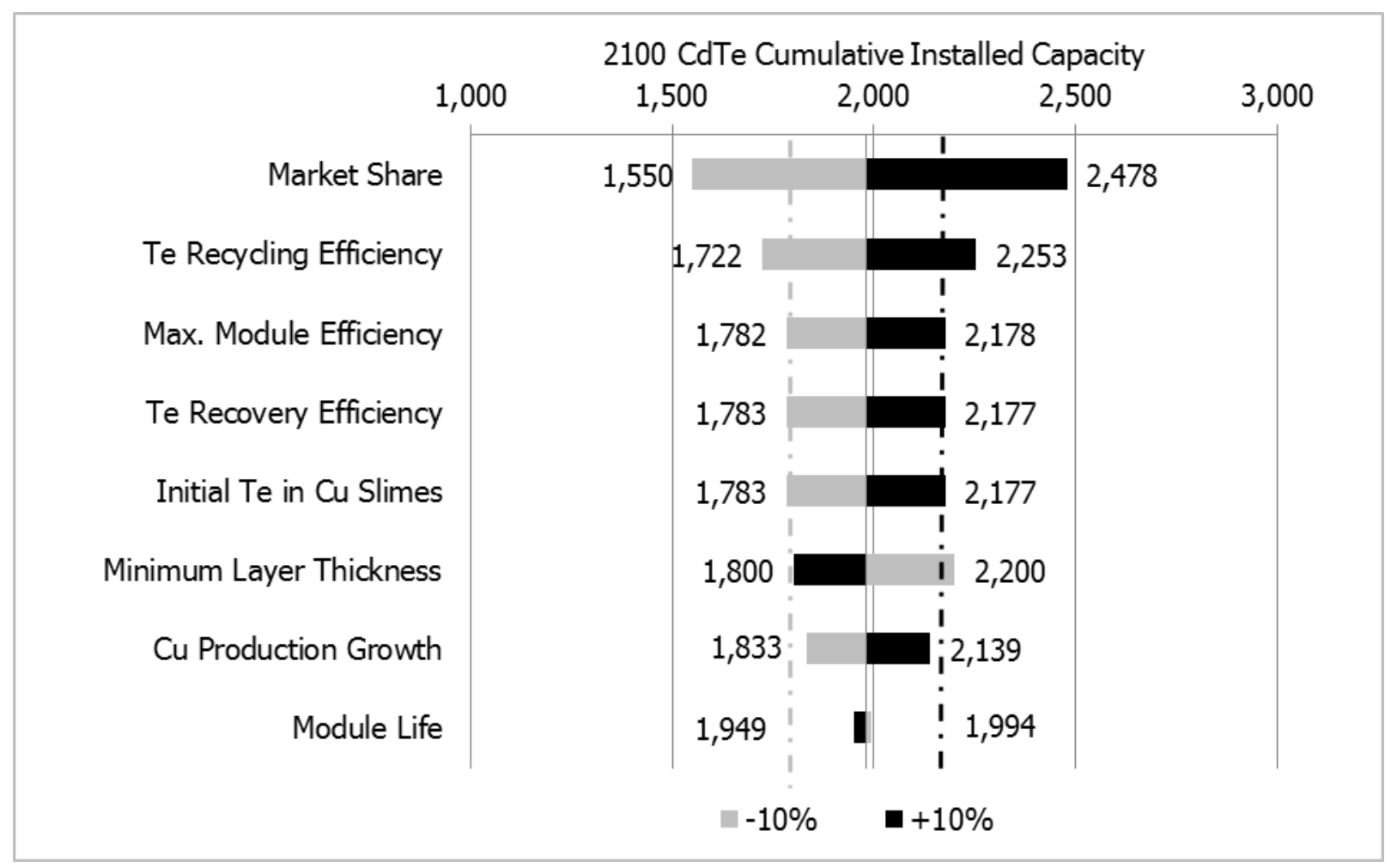

Figure 9. Sensitivity analysis of technically feasible CdTe installed capacity from old-scrap supply with $+/-10 \%$ change in Reference Case input levels for the year 2100 (Market Share: The PV share of total mineral consumption in the market; Te Recovery Efficiency: The efficiency with which tellurium is recovered from copper anode slimes; Initial Te in Cu Slimes: The initial content of tellurium in anode slimes). 


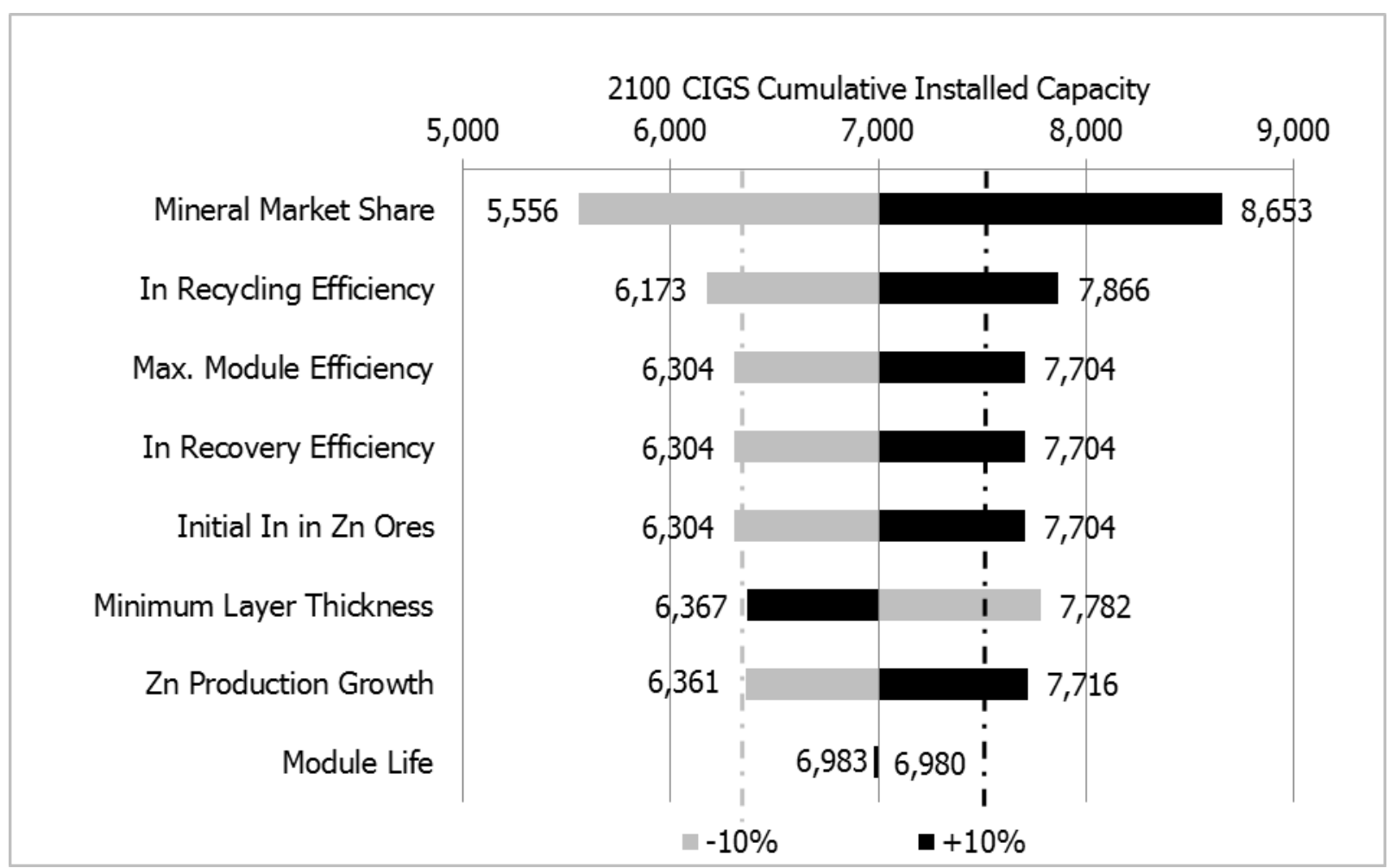

Figure 10. Sensitivity analysis of technically feasible CIGS installed capacity from old-scrap supply for the year 2100 , based on indium availability with $+/-10 \%$ change in Reference Case input levels (Market share: PV's share of total mineral consumption in the market; In recovery efficiency: the efficiency with which indium is recovered from zinc ores; Initial In in Zn ores: initial content of indium in zinc ores). 


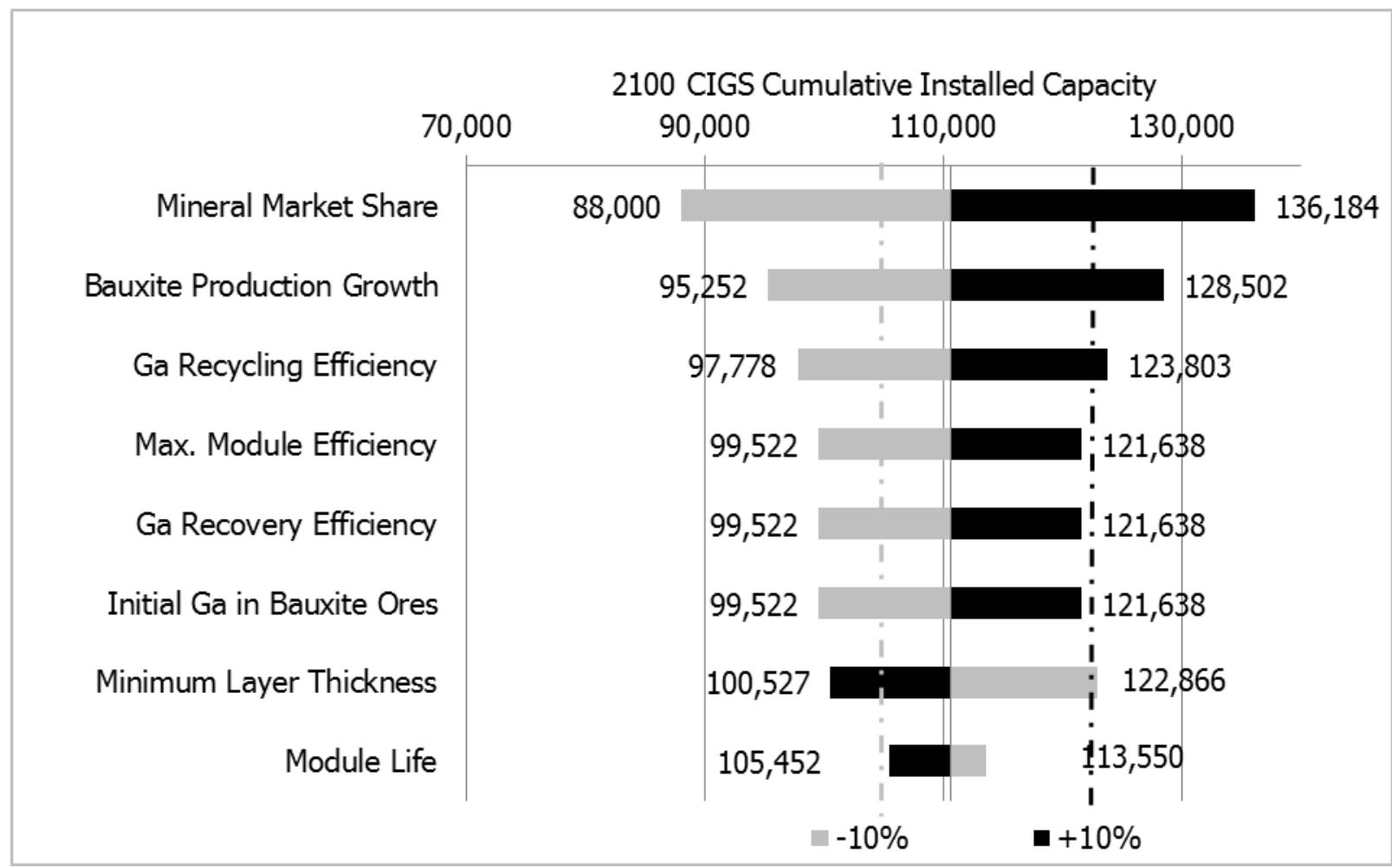

Figure 11. Sensitivity analysis of technically feasible CIGS installed capacity from old-scrap supply based on gallium (Ga) availability (and ignoring In availability), with $+/-10 \%$ change in Reference Case input levels, for the year 2100 (Market share: PV's share of total mineral consumption in the market; Ga recovery efficiency: the efficiency in which gallium is recovered from bauxite ores; Initial Ga sin Bauxite Ores: initial content of gallium in bauxite ore).

Figure 12 presents a sensitivity analysis of the tellurium contribution to CdTe module manufacturing cost in real 2012 dollar terms. A +/-10\% change in any of the inputs has about a $+/-10 \%$ change in the tellurium cost in 2050 example. Thus, there is no one input for which a variation in its Reference Case value has a significantly greater effect on cost as compared to other inputs. Similar figures for indium and gallium cost are not shown here, but the results are very similar to the sensitivity analysis for tellurium, for which a $+/-10 \%$ variation of each input results in a $+/-10 \%$ change in cost. 


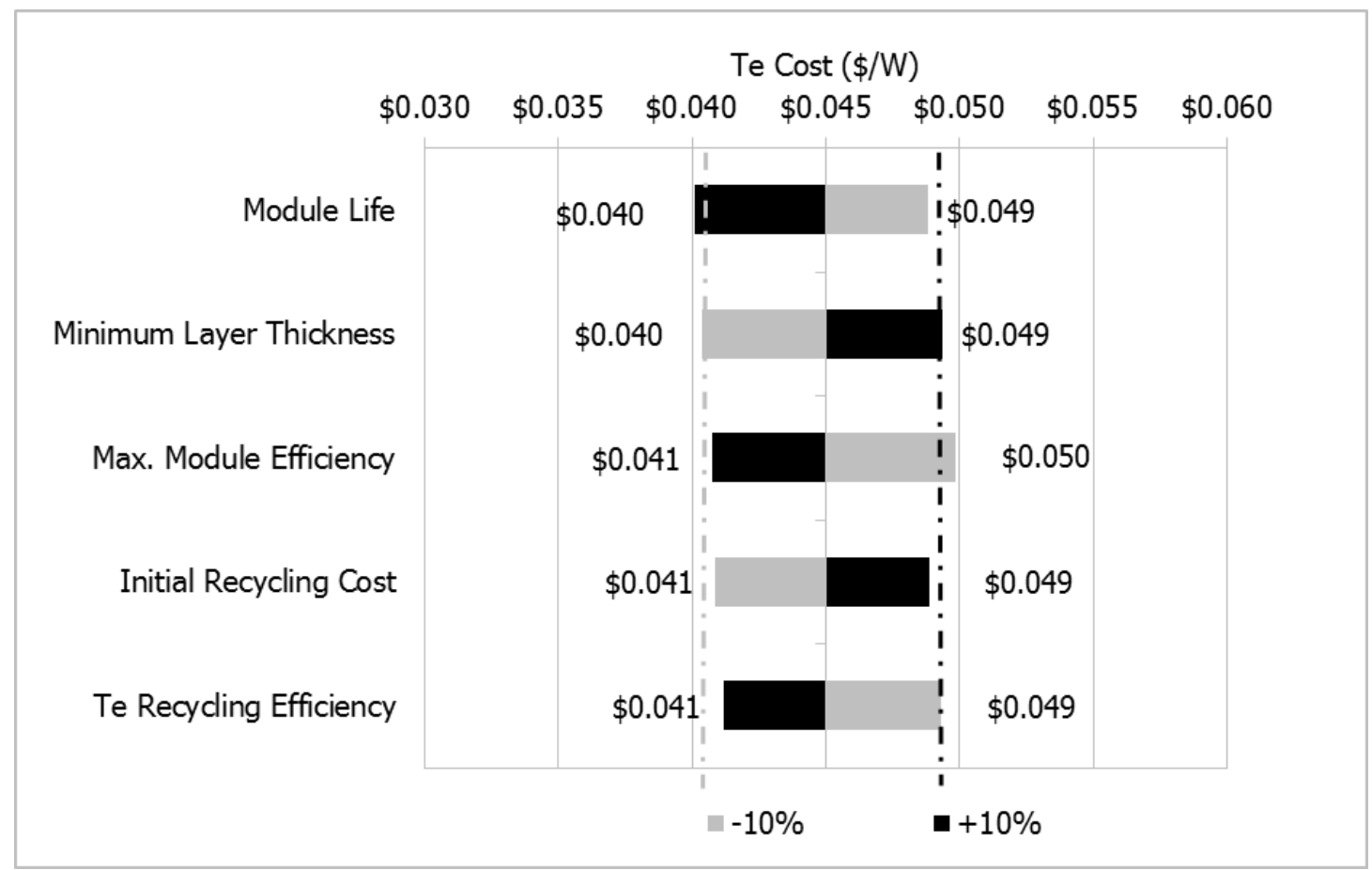

Figure 12. Sensitivity analysis of tellurium cost for CdTe Modules with $+/-10 \%$ change in Base Case input levels for the year 2050. Costs are in Real 2012 dollar terms.

\section{Conclusion}

This analysis evaluates the technical potential of CIGS and CdTe module deployment from old scrap mineral supplies of gallium, indium, and tellurium, in terms of both the quantities of CdTe and CIGS modules produced, and the cost of recovery and reuse in PV manufacturing. In terms of quantities, relatively high levels of CdTe and CIGS module deployment (on the order of more than $100 \mathrm{GW} /$ year) may be technically possible using old scrap mineral supply. Because of the small levels of historical CdTe and CIGS module production and the expected 25-year module life, however, large-scale recycling is not expected to develop for many years. Additionally, in all cases the results show that if primary mineral production continues at historical rates, then byproduct supply will likely be the largest technically feasible source (approximately 60\% to 90\%) of total gallium, indium, and tellurium used in PV manufacturing; recovered sources will supplement this primary economic supply for all three minerals. However, if the cost of recycling remains higher than recovering these elements from ores, and if primary supply is able to meet total mineral demand, then secondary may not be a relevant part of overall supply. 
In terms of costs, recovering each element from end-of-life PV modules and reusing in PV manufacturing is expected to cost more than current raw mineral costs. These results should be viewed with some caution, however, due to the uncertainty about future recycling cost and because this analysis does not take into account economies of scale or learning economies that could help reduce recycling costs over time.

Future work can help provide better estimates of PV recycling costs. Increased PV deployment occurred fairly recently, so there is little current PV recycling and, thus, little information regarding recycling costs. Interest in PV recycling has grown in recent years, as PV modules came under the scope of the European Union WEEE directive in 2014, requiring manufacturers to plan for end-of-life recycling. As better information on PV recycling becomes available, improved estimates of PV recycling costs and mineral recovery efficiency can be used to refine model assumptions and to better understand the role of recycling in enabling future production of CIGS and CdTe modules. 


\section{References}

[1] ] U.S. DOE, SunShot Vision Study, February 2012.

http://www1.eere.energy.gov/solar/pdfs/47927.pdf. Accessed October 4, 2014.

[2] U.S. DOE, Cadmium Telluride, November 20, 2013.

http://www.energy.gov/eere/sunshot/cadmium-telluride. Accessed August 6, 2014.

[3] U.S. DOE, Copper Indium Gallium Diselenide, November 20, 2013.

http://energy.gov/eere/sunshot/copper-indium-gallium-diselenide. Accessed August 6, 2014.

[4] M. Lokanc, R. Eggert, M. Redlinger, The Immediate, Medium Term, and Long Term Availability of Indium and Tellurium, National Renewable Energy Laboratory, Golden, CO, Forthcoming 2014.

[5] H.G. Dill, The "chessboard" classification scheme of mineral deposits: mineralogy and geology from aluminum to zirconium, Earth-Sci. Revs. 100 (2010) 1-420.

[6] U. Schwarz-Schampera, P. M. Herzig, Indium, Springer-Verlag, Berlin, Germany, 2002.

[7] W.L. Pohl, Economic Geology: Principles and Practice, Wiley-Blackwell, Oxford, 2011.

[8] V. Fthenakis, Sustainability of photovoltaics: The case for thin-film solar cells, Renew. \& Sustainable Energy Revs. 13 (2009) 2746-50.

[9] Y. Hourai, J. Speirs, C. Candelise, R. Gross, A system dynamics model of tellurium availability for CdTe PV, Prog. in Photovolt.: Res. \& Appl. 22 (2013) 129-46.

[10] V. Fthenakis, C. Eberspacher, P. Moskowitz, Recycling strategies to enhance the commercial viability of CIS photovoltaics, Prog. in Photovolt.: Res. \& Appl. 4 (1996) 447-56.

[11] J.-K. Choi, V. Fthenakis, Economic feasibility of recycling photovoltaic modules, J. Ind. Ecol. 14 (2010) 947-64.

[12] N. McDonald, J. Pearce, Producer responsibility and recycling solar photovoltaic modules, Energy Policy 38 (2010) 7041-47. 
[13] M. Woodhouse, A. Goodrich, R. Margolis, T. L. James, M. Lokanc, R. Eggert, Supplychain dynamics of tellurium, indium, and gallium within the context of PV module manufacturing costs, IEEE J. Photovol. (2012) 1-5.

[14] M. Woodhouse, A. Goodrich, R. Margolis, T. James, R. Dhere, T. Gessert, T. Barnes, R. Eggert, D. Albin, Perspectives on the pathways for cadmium telluride photovoltaic module manufacturers to address expected increases in the price for tellurium, Sol. Energy Maters. \& Sol. Cells 115 (2013) 199-212.

[15] V.M. Fthenakis, Life cycle impact analysis of cadmium in CdTe PV production, Renew. \& Sustainable Energy Rev. 8 (2004) 303-34.

[16] First Solar, First solar module collection and recycling program, 2010. http://www.energye.eu/download/riciclaggio_fs2_en.pdf. Accessed July 22, 2014.

[17] EU, Report on Critical raw Materials for the EU, 2014. European Commission, http://ec.europa.eu/enterprise/policies/raw-materials/files/docs/crm-critical-materialprofiles_en.pdf. Accessed September 5, 2014.

[18] P. Willis, A. Chapman, A. Fryer, Study of By-Products of Copper Lead, Zinc, and Nickel, prepared by Oakdene Hollins for the International Lead and Zinc Study Group, International Nickel Study Group, and International Copper Study Group, 2012. http://www.oakdenehollins.co.uk/media/295\%20Summ/ByProducts_Report_Executive_Summary_version_on_website.pdf. Accessed July 23, 2014.

[19] T. Prior, D. Giurco, G. Mudd, L. Mason, J. Behrisch, Resource depletion, peak minerals and the implications for sustainable resource management, Glob. Environ. Change, 22(3) (2012) $577-87$.

[20] D. May, T. Prior, D. Cordell, D. Giurco, Peak minerals: theoretical foundations and practical application, Nat. Resour. Res. 21(1) (2012) 43-59.

[21] J.E. Tilton, G. Lagos, Assessing the long-run availability of copper, Resour. Policy 1(32) (2007) 19-23. 
[22] F. Ojebuoboh, First Solar \& Supplementing Byproduct Tellurium for the Evolving CdTe Solar Market, Colorado: Presentation to the Denver Mining Club, 2011.

[23] R. Moss, E. Tzimas, H. Kara, P. Willis, J. Kooroshy, Critical Metals in Strategic Energy Technologies, European Commission Joint Research Centre Institute for Energy and Transport, 2011.

[24] V.M. Fthenakis, End-of-life management and recycling of PV modules, Energy Policy 28(14) (2000) 1051-58.

[25] C. Eberspacher, C. F. Gay, P. D. Moskowitz, Strategies for Recycling CdTe Photovoltaic Modules, Presented at the 1st World Conference on Photovoltaic Energy Conversion, Waikoloa, HI, 1994.

[26] P. Moskowitz, K. Zweibel, Recycling of cadmium and selenium from photovoltaic modules and manufacturing wastes, March 1992, http://www.osti.gov/scitech/servlets/purl/10103235. Accessed July 23, 2014.

[27] J. Montgomery, US PV recycling: the solar industry needs a plan now, Renewable Energy World, October 25, 2013. http://www.renewableenergyworld.com/rea/news/article/2013/10/uspv-recycling-the-solar-industry-needs-a-plan-now. Accessed July 23, 2014.

[28] L. Krueger, Brokhaven National Laboratory, n.d., http://www.bnl.gov/pv/files/PRS_Agenda/2_Krueger_IEEE-Presentation-Final.pdf. Accessed July 23, 2014.

[29] Xsunx, Preliminary Specification Sheet CIGS Thin Film Solar Modules, April 1, 2009. http://www.xsunx.com/pdf/CIGSBrochure-draft.pdf. Accessed July 23, 2014.

[30] First Solar, "First Solar Annual 10-k," 29 February 2012. [Online]. Available: http://www.sec.gov/Archives/edgar/data/1274494/000127449412000015/fslrdec1110k.htm. [Accessed 12 August 2014].

[31] First Solar, "First Solar Annual 10-k," 22 February 2010. [Online]. Available: http://www.sec.gov/Archives/edgar/data/1274494/000127449410000007/0001274494-10000007-index.htm. [Accessed 12 August 2014]. 
[32] First Solar, "First Solar Annual 10-k," 28 February 2011. [Online]. Available: http://www.sec.gov/Archives/edgar/data/1274494/000127449411000007/fslrdec1010k.htm. [Accessed 12 August 2014].

[33] B.W. Jaskula, Gallium, February 2014.

http://minerals.usgs.gov/minerals/pubs/commodity/gallium/mcs-2014-galli.pdf. August 10, 2014

[34] E.L. Bray, Bauxite and Aluminum, January 2013.

http://minerals.usgs.gov/minerals/pubs/commodity/bauxite/mcs-2013-bauxi.pdf. July 23, 2014.

[35] D.A. Kramer, Gallium and Gallium Arsenide: Supply, Technology, and Uses (Information Circular 9208), United States Department of Interior, Bureau of Mines, Washington, DC, 1988.

[36] M. Moats, T. Robinson, Global Survey of Copper Electrorefining Operations and Practices, 2013.

[37] M. Green, Improved estimates for Te and Se availability from $\mathrm{Cu}$ anode slimes and recent price trends, Prog. Photovolt. Res. \& Applications 14(8) (2006) 743-51.

[38] International Copper Study Group (ICSG), 2013 Statistical Yearbook, International Copper Study Group, Lisbon, 2013.

[39] R. Watts, W. Gurwell, W. Jamieson, L. Long, W. Pawlewicz, S. Smith, R. Teeter, The Evaluation of Critical Materials for Five Advanced Design Photovoltaic Cells with an Assessment of Indium and Gallium, Pacific Northwest Laboratory, Richland, Washington 1980.

[40] Z. Zhao, Y. Yang, Y. Xiao, Y. Fan, Recovery of gallium from Bayer liquor: a review, Hydrometall. 125-126 (2012) 115-24.

[41] S. Wang, Tellurium, its resourcefulness and recovery, JOM: J. Minerals, Met. \& Mater. Society (TMS) 63(8) (2011) 90-93.

[42] B.H. Morrison, Slimes Treatment Process. U.S. Patent \# 4,047,939, September 13, 1977.

[43] Y. Ha, H. Sohn, G. Jeong, C. Lee, K. Rhee, Electrowinning of tellurium from alkaline leach liquor of cemented Te, J. Appl. Electrochem. 30 (2000) 315-22. 


\section{Appendix. Estimates of Primary Supply of Gallium, Indium, and Tellurium}

This appendix provides additional details on the estimates for primary supply of gallium, indium, and tellurium. In particular, it presents the estimates for gallium content of bauxite production in 2012, tellurium content of copper anode slimes produced in 2012, potential gallium recovery efficiency from bauxite ores, and potential tellurium recovery efficiency from copper anode slimes.

\section{Gallium Content of Bauxite}

The vast majority of refined gallium produced comes from bauxite. Table A.1 shows bauxite production by country, estimated average gallium concentration by country, and the resulting estimated gallium mine production in 2012. Current production is about 300 tonnes per year [33], only about $2 \%$ of available gallium is being recovered.

Table A.1. Gallium Content of 2012 Global Bauxite Production

\begin{tabular}{lrrr} 
Country & $\begin{array}{r}2012 \text { Bauxite } \\
\text { Mine Production } \\
(\mathrm{mt})\end{array}$ & $\begin{array}{r}\text { Gallium } \\
\text { Concentration } \\
(\mathrm{ppm})\end{array}$ & $\begin{array}{r}\text { 2012 Gallium } \\
\text { Mine Production } \\
\text { (tonnes) }\end{array}$ \\
\hline United States & $\mathrm{NA}$ & 70 & 0 \\
Australia & 73.0 & 60 & 4,380 \\
Brazil & 34.0 & 50 & 1,700 \\
China & 48.0 & 60 & 2,880 \\
Greece & 2.0 & 30 & 60 \\
Guinea & 19.0 & 30 & 570 \\
Guyana & 1.9 & 50 & 93 \\
India & 20.0 & 70 & 1,400 \\
Indonesia & 30.0 & 40 & 1,200 \\
Jamaica & 10.3 & 60 & 618 \\
Kazakhstan & 5.3 & 50 & 265 \\
Russia & 6.1 & 50 & 305 \\
Sierra Leone & 1.2 & 40 & 48 \\
Suriname & 4.2 & 80 & 336 \\
Venezuela & 4.5 & 30 & 135 \\
Vietnam & 0.3 & 50 & 15 \\
Other Countries & 3.1 & 50 & 155 \\
World Total & 263 & & 14,160 \\
\hline
\end{tabular}


Notes

a. NA means "not available."

b. Sources: Bauxite production data [34], Gallium content of ores [35] with the exception of Kazakhstan, Vietnam, and other countries, which are assumed to be $50 \mathrm{ppm}$.

\section{Tellurium Content of Copper Anode Slime}

Nearly all tellurium produced is recovered from copper anode slimes produced during the refining of copper anode into copper cathode. Table A.2 shows the estimated tellurium content of copper anode slimes. This is calculated from copper anode slime data reported from copper refineries in 2013 in the global copper survey conducted by Moats and Robinson [36]. It is estimated that 1,305 tonnes of tellurium was available for recovery from copper anode slimes in 2012. This is very close to Green's estimate of 1,300 [37]. Note that tellurium production is estimated to be approximately 450 tonnes per year [17], implying that about 35\% of available tellurium currently is recovered.

Table A.2 Tellurium Content of 2012 Global Copper Anode Slime Production

\begin{tabular}{|lrc|}
\hline & & Notes \\
Average Slime Generation (kg/tonne of anode) & 5.7 & 1 \\
Copper Smelter Production from Primary Feed (tonnes) & $13,137,500$ & 2 \\
Average Copper Anode Copper Grade (\%) & $99 \%$ & 3 \\
Estimated Anode Production-Primary Feed (tonnes) & $13,234,001$ & 4 \\
Estimated Anode Slime Production (tonnes) & 74,779 & 5 \\
Average Tellurium Grade & $1.75 \%$ & 6 \\
Total Tellurium Content of Anode Slimes & 1,305 & 7 \\
& & \\
Notes & & \\
& & \\
1. This is the kilograms of anode slime generated per tonne of copper anode produced and \\
is the average of the slime generation reported by copper refineries [36]. \\
2. Source for copper smelter production from primary feed is ICSG [38]. \\
3. Calculated as the average of copper anode grade for refineries [36]. \\
4. Calculated as the copper smelter production divided by copper grade of anode. \\
5. Calculated as (Average Slime Generation)*(Estimated Anode Slime Production)/1,000. \\
6. Calculated as the average tellurium grade of refineries [36] \\
7. Calculated as (Estimated Anode Slime Production)*(Average Te Grade). \\
\hline
\end{tabular}




\section{Gallium Recovery Efficiency from Bauxite Ore}

To estimate the potential recovery efficiency for gallium from bauxite ores, a bottom-up analysis of the gallium supply chain is used to calculate the technical recovery efficiency at each stage and determine an estimate for the overall recovery efficiency. Figure A.1 shows the estimated gallium recovery efficiency from bauxite ore at each step in the gallium-production process. Alumina, the precursor to aluminum, is produced from bauxite ore through the Bayer process. During this process, the gallium-enriched Bayer liquor recirculating through the process stages can be diverted and used as feedstock for gallium recovery of crude gallium (97\% to 99.9\% gallium purity).

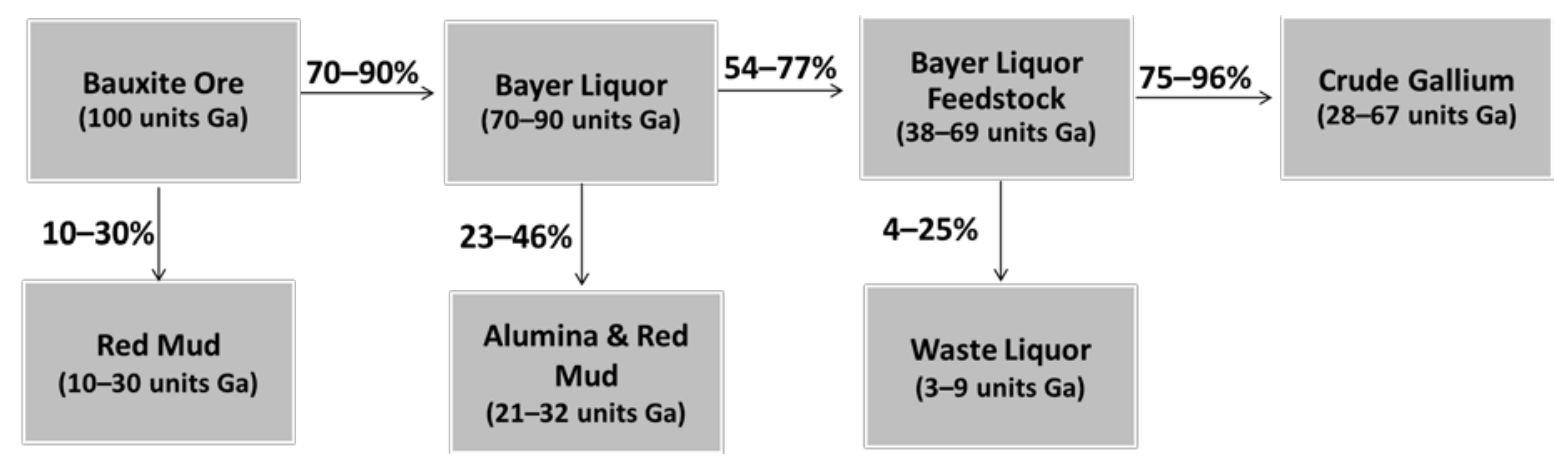

Figure A.1. Gallium recovery efficiency from Bauxite ore

The "bauxite ore" stage represents the amount of gallium contained in bauxite. Watts et al. [39] estimate that $10 \%$ of gallium contained in bauxite initially is lost in red mud, which is generated after the digestion and clarification stages of alumina refining. Zhao et al. [40] report that 30\% of the gallium is lost in red mud.

In the "Bayer liquor" stage, gallium is present in this solution and the opportunity exists for alumina refiners to divert a portion of the circulating Bayer liquor to a gallium-recovery circuit. The portion of Bayer liquor that is diverted depends on several factors, including the galliumrecovery capacity and the operational needs of the Bayer process. Alumina refining is primary focus, therefore it likely that only a small amount of Bayer liquor will be diverted to a galliumrecovery circuit, so as to not disrupt alumina refining operations. Watts et al. [39] state that it is likely that due to the diminishing returns to processing additional Bayer liquor, only about 5\% to 
$10 \%$ of the Bayer liquor will be diverted to a gallium-recovery circuit. Watts et al. calculate that with $10 \%$ loss to red mud, 5\% of the Bayer liquor being diverted, and $75 \%$ recovery of gallium in the diverted liquor, $36.37 \%$ of the gallium contained in the bauxite ore is recovered as gallium metal. When $10 \%$ of the solution is diverted the recovery efficiency is $51.97 \%$. Using these total recovery efficiencies and the known recovery efficiencies of the other stages, the estimate of percentage of gallium contained in the Bayer liquor that ends up as feedstock in the galliumrecovery circuit is 53.88\% when 5\% $((36.67 \% / 90 \%) / 75 \%=53.88)$ is diverted and $77.00 \%$ when $10 \%$ is diverted $((51.97 \% / 90 \%) / 75 \%=77.00 \%)$.

Lastly, in the Bayer liquor feedstock stage, the percent of the Bayer liquor feedstock that is recovered as crude gallium metal depends upon the recovery processes being used. Watts et al. assume a recovery efficiency of 75\% in stage, but Zhao et al. note that efficiency can reach $96 \%$. This analysis uses a range of $75 \%$ to $96 \%$ to allow for a variety of potential recovery efficiencies. Currently,

\section{Tellurium Recovery Efficiency from Copper Anode Slime}

Table A.3 shows a bottom-up estimate of technical recovery efficiency of tellurium from copper anode slime. In the process evaluated here, copper anode slime undergoes acid pressure leaching in an autoclave, which produces detellurized slime and a leached liquor containing tellurium. The leached liquor then undergoes cementation with copper shots to form copper telluride. The copper telluride then leached with sodium hydroxide to form a sodium tellurium solution, which then undergoes electrowinning. The recovery-efficiency estimates come from various sources, and cautions related to the data are given in the notes for Table A.3. The present bottom-up analysis gives a base case recovery efficiency of tellurium from copper anode slime with current technologies of $72 \%$. This is slightly less than other estimates of recovery given current technologies of $80 \%$ [21] and $~ 90 \%$ [22]. Given the uncertainty over recovery estimates, this analysis use a range of $70 \%$ to $90 \%$ with a base case of $80 \%$.

Table A.3. Tellurium Recovery Efficiency from Copper Anode Slime

\begin{tabular}{|lccc|}
\hline \multicolumn{1}{|c}{ Stage } & Efficiency & $\begin{array}{c}\text { Cumulative } \\
\text { Efficiency }\end{array}$ & Notes \\
Copper Anode Slime & NA & NA & \\
Acid Pressure Leaching in Autoclave & $90 \%$ & $90 \%$ & a \\
\hline
\end{tabular}




\begin{tabular}{|c|c|c|c|}
\hline lel & $85 \%$ & $77 \%$ & b \\
\hline ith Sodium Hydroxide & $99 \%$ & $76 \%$ & C \\
\hline & 6 & $\%$ & d \\
\hline \multicolumn{4}{|c|}{$\begin{array}{l}\text { Notes } \\
\text { a. Wang [41] reports that when using acid pressure leaching processes, about } 70 \% \text { to } 80 \% \text { of } \\
\text { the tellurium is extracted, but more than } 90 \% \text { of the tellurium can be recovered. } \\
\text { b. Morrison [42] reports recovering at least } 85 \% \text { of the tellurium during cementation. } \\
\text { c. Ha et al. [43] report that } 99 \% \text { of tellurium is extracted in sodium hydroxide leaching. This } \\
\text { estimate should be used with caution as it is not based on commercial processes but rather } \\
\text { laboratory processes. } \\
\text { d. Ha et al. [43] report that } 95 \% \text { of tellurium is recovered through electrowinning. This } \\
\text { estimate should be used with caution as it is not based on commercial processes but rather } \\
\text { laboratory processes. }\end{array}$} \\
\hline
\end{tabular}

